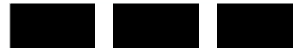 \\ am \\ The WiLliam DAVIDSON INSTITUTE \\ AT THE UNIVERSITY OF MICHIGAN
}

\section{Minimum Wage and Tax Evasion: Theory and Evidence}

\author{
By: Mirco Tonin
}

William Davidson Institute Working Paper Number 865 January 2007 


\title{
Minimum Wage and Tax Evasion: Theory and Evidence
}

\author{
Mirco Tonin*
}

January 30, 2007

\begin{abstract}
The paper investigates the role of the minimum wage in a competitive economy in which there is underreporting of earnings by employed labour. The minimum wage induces higher compliance by some lowproductivity workers and transforms a nominally neutral fiscal system into a regressive one. A spike in the wage distribution at the minimum wage level appears and a positive correlation between the size of the spike and the size of the informal economy is predicted and documented using cross-country data for Europe. A further result is that employees whose officially declared earnings appear to be boosted by a minimum wage hike actually experience a decline in their true income. This prediction finds support in an empirical test using the massive increase in the minimum wage that took place in Hungary in 2001 as a quasi-natural experiment.
\end{abstract}

JEL codes: J38, H26, H32, P2

Keywords: Minimum Wage, Tax Evasion, Wage Distribution, Hungary

*Institute for International Economic Studies, Stockholm University, tonin@iies.su.se I thank the Department of Economics at CEU and the Hungarian National Bank, where part of this research was conducted, for their hospitality. I also thank the Institute of Economics at the Hungarian Academy of Sciences for its hospitality and for providing the data. Comments and suggestions by John Hassler, György Molnár, Peter Fredriksson, Gabor Kezdi, Ethan Kaplan, János Köllő, David Strömberg, Torsten Persson and several seminar and conference participants have been greatly helpful. I am grateful to Christina Lönnblad for editorial assistance. Financial support by Jan Wallander's and Tom Hedelius' Research Foundation is gratefully acknowledged. 
"Did you know that more than half of the people nominally employed at the minimum wage earn more, and the only reason for such a declaration is to evade taxes and social security contributions? " $^{\text {" }}$

(Advertisement in Metro newspaper for the Hungarian government Green Book, 22 September 2006)

\section{Introduction}

What are the fiscal implications of introducing or increasing the minimum wage? How can we explain the very high spike at the minimum wage level appearing in the wage distribution of some countries? This paper contributes to answering these questions by studying the effects of the interaction between tax evasion and minimum wage legislation.

The minimum wage is the subject of a rich literature and policy debate ${ }^{2}$, mainly focusing on its effect on employment. The traditional view of adverse labour market effects has been challenged (Card and Krueger, 1995) and at present, there is no overwhelming consensus on the issue. Potential beneficial effects of the minimum wage for workers through shifts in the composition of jobs toward good (i.e. high-wage) jobs have also been discussed (Acemoglu, 2001.) This paper highlights another aspect of minimum wage policy that has not been considered so far and shows how an increase in the minimum wage can make affected workers worse off through the "fiscal channel", even if they do not experience adverse labour market effects.

Large efforts have also been devoted to the theoretical and empirical study of tax evasion and the shadow economy ${ }^{3}$. The study of tax evasion by employed labour is of particular interest as the fiscal imposition on labour in the form of social security contributions (SSC) and personal income tax (PIT) represents the bulk of fiscal revenues in many countries ${ }^{4}$. However, to the best of my knowledge, the effects of the interaction between underreporting

\footnotetext{
1 "Tudta, hogy a papíron minimálbérért dolgozók több mint fele többet keres annál, és csak azért van minimálbérre bejelentve, hogy kikerülje az adó- és járulékfizetést?" (own translation)

${ }^{2}$ See Brown (1999) for a review.

${ }^{3}$ See Andreoni et al. (1998) or Slemrod and Yitzhaki (2002) for surveys on tax evasion and Schneider and Enste (2000) for a survey on the shadow economy.

${ }^{4}$ In EU15 as a whole, labour taxes contributed around $50 \%$ of the total tax receipts in 2002 (Eurostat, 2004.)
} 
of earnings and minimum wage legislation have not previously been addressed in a formal model.

Undeclared work is a serious issue in many countries. It is difficult to obtain reliable data on its extension, but raw estimates indicate that the phenomenon is relevant, particularly in transition and developing countries but also in some OECD economies. In a report for the European Commission, the authors stress how the practice of paying "envelope wages" above the officially declared minimum "exists in practically all of the Central and Eastern European countries" (Renooy et al., 2004.) An OECD study of the Baltic countries (OECD, 2003) estimates that in Latvia and Lithuania, 20\% of the private-sector employees earn more than what is officially reported ${ }^{5}$. Similar figures have been estimated for Bulgaria (Tomev, 2004.) In Russia, $8 \%$ of the employees reported that they received part of their income "under the table" (Petrova, 2005.) The phenomenon is not limited to CEE economies. OECD estimates a 30\% shortfall in social security contributions due to undeclared work for Hungary, Mexico and South Korea, and a shortfall above 20\% for Italy, Poland, Spain and Turkey ${ }^{6}$ (OECD, 2004.) A World Bank study on labour markets in Eastern Europe and the Former Soviet Union (World Bank, 2005) notices how in several countries in the region "disproportionately high shares of workers cluster on declared wages at or just above the minimum wage (with evidence of additional undeclared incomes above the minimum), creating incentives to sustain a high minimum wage to sustain tax revenue" and calls for further research on this aspect of minimum wage policy. This is indeed the aim of the paper.

A simple model of the labour market is created, where underreporting of earnings is made possible by imperfect detection of tax evasion. The introduction of the minimum wage induces some worker-firm pairs to increase compliance, while pushing others out of the formal labour market into the black economy or into inactivity. The increase in compliance is due to the fact that the minimum wage poses a constraint to reporting behaviour, as agents must choose whether to report nothing or report at least the minimum

\footnotetext{
${ }^{5}$ The Latvian Central Statistical Office publishes data on earnings under the heading "Gross wage of employed excluding all kinds of irregular payments by kind of activity" (italics added.)

${ }^{6}$ In Turkey, firms belonging to the formal sector are estimated to underreport $28 \%$ of their wage bill and for around 50\% of the employees enrolled in SSK (Social Security Organization), wages reported by employers are at the minimum insurable level (World Bank, 2006.)
} 
wage. When faced with such a restriction, agents may prefer to increase their reporting to the minimum wage level rather than decreasing it to zero. The overall effect when enforcement is not too effective is to unambiguously increase fiscal revenues. The distribution of the fiscal burden is also altered, turning a nominally neutral fiscal regime into a regressive one. Moreover, an otherwise smooth distribution of declared earnings is transformed by the introduction of the minimum wage into a distribution presenting a spike at the minimum wage level.

The model predicts that a minimum wage hike implies a fall in true income for those workers officially earning between the old and the new minimum wage before the hike, even if they keep their job. The massive increase in the minimum wage that took place in Hungary in 2001 provides a natural experiment to test this prediction. Panels derived from the household budget survey for the years 1999-2001 are used to compare consumption, as a proxy for true income, before and after the increase in the minimum wage for households affected by this and for similar but unaffected households. The analysis suggests that the minimum wage hike was indeed effective in squeezing more fiscal revenues from affected households, thus supporting the prediction of the theory.

The model also predicts a positive correlation between the size of the spike at the minimum wage level and the size of the informal economy. Supporting empirical evidence is presented.

The next section discusses some of the related literature. The model is introduced in the third section. In section 4, the various effects of introducing the minimum wage are explored. Section 5 looks at the model implications for the relationship between the spike at the minimum wage and the underground economy. The following section tests one of the model predictions using Hungarian data. In section 7, some evidence about the relationship between the spike and the underground economy is presented. The last section concludes.

\section{Related literature}

The literature on tax evasion has mainly been focused on personal income tax and the compliance decision by an individual filling the tax declaration form. However, due to the tax withholding and information reporting systems present in many countries, this is not an accurate description for the 
case of employed labour. Indeed, the rate of non-compliance for wages and salaries at the stage of filling the tax declaration form is often negligible. For instance, Klepper and Nagin (1989) report a mere $0.1 \%$ of non-compliance for wages and salaries at this stage in the US, i.e. lower than for any other income category. Therefore, to study tax evasion by employed labour it is necessary to take into account the interaction between the employer and the employee.

The literature specifically looking at the labour market effects of tax evasion often considers the formal and informal sections of the labour market as separate, with workers and firms being either completely underground or completely compliant with the regulation. Boeri and Garibaldi (2005) are a recent example of this. Fugazza and Jacques (2003) also take this approach in their study on the effect of labour market institutions when there is an underground sector.

Another strand of the literature, in line with the view taken in this paper, considers that workers' compliance with regulation can also be partial. Sandmo (1981) and Cowell (1985) study models where working time can be allocated between the formal and informal sectors. The former is mainly interested in determining the optimal income tax and enforcement, the latter in investigating the effects of fiscal and enforcement parameters on the dimension of the informal sector. Kolm and Nielsen (2005) study a search model with wage bargaining, where the worker and the firm agree on the amount of remuneration not to be reported to the fiscal authorities. They find that both higher taxes and weaker enforcement reduce unemployment. Bargaining between the firm and the workers over the true and reported wage is also assumed by Yaniv (1992) who explores the impact of fiscal and detection parameters on tax evasion and contrasts a withholding and a selfdeclaration system. However, none of the above mentioned studies considers the impact of minimum wage legislation in an economy with underreporting.

The literature on minimum wage deals extensively with its effects on wage distribution and employment. A spike at the minimum wage level has been observed in several instances (see, for instance, DiNardo et al., 1996, Dickens and Manning, 2004.) Such a spike has been defined as a "puzzle" for several standard types of labour market models (Brown, 1999) and as an "anomalous finding from the standpoint of the standard model of the low wage labor market" (Card and Krueger, 1995, p. 152.) Proposed rationalizations include reductions in non-wage compensation or increases in required effort to offset a binding minimum wage, flatter earnings profiles and adjustments in the 
amounts of hours worked. The model presented here proposes an alternative rationale for the observed spike in a perfect competition framework. The positive correlation between the size of the spike at the minimum wage and the estimated size of the informal economy in the data presented in section 7 suggests that the mechanism analysed in this paper indeed contributes to shape the observed distribution of earnings in some countries. Recently, several empirical studies have considered the impact of the minimum wage on other aspects than employment, like fringe benefits (Simon and Kaestner, 2004), prices (Lemos, 2005), profits (Draca et al., 2006.) The impact of the minimum wage on tax evasion has, to the best of my knowledge, never been investigated.

The empirical study of tax evasion or participation in the informal economy by labour is not straightforward. One method is to design specific surveys on these issues. For example, Lemieux et al. (1994) conducted a survey with questions on participation in the underground sector in Quebec city, Canada, and find that underground labour-market activity is concentrated among people at the low end of the income distribution. Another method is based on the comparison of income or labour force participation data from different sources. For instance, Fiorio and D'Amuri (2005) estimate tax evasion in Italy by comparing income from tax forms to survey-based data and find that for employees, evasion is high at lower levels of income, but close to zero at the median.

The method used in this paper is based on the comparison of income and consumption data from household budget surveys. This methodology was pioneered by Pissarides and Weber (1989.) They study underreporting by self-employed in UK by assuming that expenditure on food is correctly reported by all income groups, while income is correctly reported by employees, but underreported by self-employed. Lyssiotou et al. (2004) use a demand system approach to take into account preference heterogeneity. They also focus on tax evasion by self-employed. Tedds (2005) uses a nonparametric approach to address the same question and finds evidence of a non-linear reporting function, with underreporting decreasing as reported self-employment income increases.

The methodology developed by Pissarides and Weber has also been used to study underreporting by private sector employees, using public sector employees as a control group assumed to correctly report income (Besim and Jenkins, 2005.) However, Gorodnichenko and Sabirianova (2006) take the opposite view in their study on bribery in Ukraine. They use the large esti- 
mated sectoral gap in reported earnings between the public and the private sector and the absence of an expenditure gap to identify the size of unreported bribes to public officials. The methodology used in this paper to investigate the impact of the minimum wage on underreporting is inspired by this strand of literature. Also in this case are expenditures on food assumed to be correctly reported. There is no need, however, to assume that a group truthfully reports income. The theoretical model makes it possible to characterize the minimum wage hike as a shock to the "underreporting technology" affecting some workers but not others and this variation is exploited to identify the impact of the minimum wage on underreporting.

\section{The model without minimum wage}

The size of the population is exogenously given and normalized to 1 . Every individual has an exogenously given productivity $y_{i}$, distributed in the population according to $\operatorname{pdf} g(y)$ and $\operatorname{cdf} G(y)$ on the support $[\underline{y}, \bar{y}]$, where $\mathbf{y} \geq 0$. We assume that the labour market is competitive, each firm employs one worker, there is no capital, and production is equal to labour input. Moreover, there is free entry of firms, firms can observe workers' productivity, and workers can move from one firm to another at no cost.

Firms are risk-neutral and maximize expected profits. In an environment without tax evasion, profits for a firm employing a worker with productivity $y_{i}$ are given by

$$
\pi_{i}=y_{i}-w_{i},
$$

where $w_{i}$ is the gross wage ${ }^{7}$. Firms have an obligation to withhold taxes and social security contributions and transfer them to the authorities. Taxation is at the proportional rate $t \in(0,1)$. Workers are risk-averse, their (indirect) utility is an increasing function of net income, given by

$$
I_{i}=w_{i}(1-t)
$$

The wedge between the gross wage paid by the firm and the net wage received by the worker, $t w_{i}$, is paid to the fiscal authorities. Free entry of firms implies that in equilibrium, the expected profits are zero which, in turn, in the full compliance case implies that a worker with productivity $y_{i}$ would receive a

\footnotetext{
${ }^{7}$ No distinction is made between labour cost and gross wage and the two concepts are considered to be equivalent in the model.
} 
gross wage $y_{i}$, from which the firm would deduct taxes $t y_{i}$, thereby leaving the worker a net wage $(1-t) y_{i}$.

In this economy, however, it is possible to evade taxes and social security contributions by not reporting part or all of the worker's earnings to the authorities. A firm employing a worker with productivity $y_{i}$ must therefore decide how much of the worker's product to declare to the tax authorities, $x_{i}$, and how much to conceal, $y_{i}-x_{i}$. If $x_{i}=y_{i}$, the firm is fully compliant with the regulations. If $x_{i}=0$, the full product is hidden from the authorities and the firm-worker pair operates completely in the black economy. If $x_{i} \in\left(0, y_{i}\right)$, there is underreporting. A worker-firm pair can thus operate in the formal economy, by declaring a strictly positive income, or be completely in the black market, by declaring nothing. A worker can also decide to be inactive. In this case, income is normalized to 0 .

Tax authorities may inspect firms to find out whether they comply with fiscal regulation. We assume there to be an exogenously given probability of an audit being performed $\gamma \in[0,1]$. Fines are imposed on firms in case tax evasion is detected and, given the assumption of risk-neutral firms and risk-averse workers, there is no incentive for workers and firms to negotiate a different risk-sharing arrangement. However, the fact that an audit is performed does not imply that the authority with certainty discovers the true tax liability, but it may find evidence to impute an income $\hat{y}_{i} \in\left[0, y_{i}\right]$, where $y_{i}$ is the true product. For instance, Feinstein (1991) estimates that IRS examiners on average managed to detect only half of the tax evasion in the forms they audited, while Erard (1997) rejects the null hypothesis of perfect detection in his empirical investigation of a model where detection can be either complete or null. For analytical convenience, we assume that the detection technology is such that the probability of finding an imputable product $\hat{y}_{i}$ is uniform over the interval $\left[0, y_{i}\right]$, i.e. $\hat{y}_{i} \sim U_{\left[0, y_{i}\right]}$. However, the problem is well defined for any distribution characterized by a differentiable density function.

Given a declaration of $x_{i}$ and collected evidence of a true tax liability of $\hat{y}_{i}$, the tax authority imposes on the firm, in case $\hat{y}_{i}>x_{i}$, the payment of $\theta t\left(\hat{y}_{i}-x_{i}\right)$, consisting of taxes plus an additional fine proportional to the assessed tax evasion, thus $\theta>1$. In case $\hat{y}_{i} \leq x_{i}$, the tax authority cannot prove any tax evasion, so no fine is imposed. Given a true product $y_{i}$ and a 
reported one $x_{i} \in\left[0, y_{i}\right]$, the expected fine in case of auditing, $f_{i}$, is

$$
f_{i}=t \theta \int_{x_{i}}^{y_{i}}\left(\hat{y}_{i}-x_{i}\right) g\left(\hat{y}_{i}\right) d \hat{y}_{i}, \quad \text { where } \quad g\left(\hat{y}_{i}\right)=\frac{1}{y_{i}}
$$

Then,

$$
f_{i}=\frac{t \theta}{y_{i}} \int_{x_{i}}^{y_{i}}\left(\hat{y}_{i}-x_{i}\right) d \hat{y}_{i}=\frac{t \theta}{2 y_{i}}\left(y_{i}-x_{i}\right)^{2} .
$$

Notice that a decrease in reported income, $x_{i}$, does not increase the probability that any particular level of income is detected, as this probability is given. However, it increases the probability of paying a fine, as a fine is imposed on the difference between detected and reported income, if positive. Given the detection technology, the expected fraction of evaded income, $y_{i}-x_{i}$, that is discovered in case of auditing is

$$
\frac{1}{y_{i}-x_{i}}\left[\frac{1}{y_{i}} \int_{x_{i}}^{y_{i}}\left(\hat{y}_{i}-x_{i}\right) d \hat{y}_{i}\right]=\frac{y_{i}-x_{i}}{2 y_{i}}
$$

i.e. a fraction corresponding to half the ratio of evaded income over true product. The assumption is thus that it is relatively easy to get away with tax-evasion.

Below, we determine the equilibrium wage and evasion. For convenience, subscripts are suppressed where not necessary.

\subsection{Equilibrium without minimum wage}

For a firm employing a worker with productivity $y$, declaring $x$, and paying a gross wage $w$, the possible realizations of profits are given by ${ }^{8}$

$$
\pi=\left\{\begin{array}{ll}
y-w & \text { with probability } 1-\gamma \\
y-w-f & \text { with probability } \gamma
\end{array},\right.
$$

\footnotetext{
${ }^{8}$ Actually, when an audit is performed, possible realizations of profits are a continuum, due to the stochastic nature of the fine. For expositional convenience, the expected value of the fine is considered.
} 
where $f$, the expected fine in case an audit is conducted, is given by (1). Therefore, expected profits for the firm are

$$
E(\pi)=y-w-\gamma f
$$

Substituting (1) into (3), we get

$$
E(\pi)=y-w-\gamma \theta t \frac{1}{y} \frac{1}{2}(y-x)^{2} .
$$

The firm chooses both $w$ and $x$ to maximize its profits.

Income $I$ for a worker employed in a firm paying a gross wage $w$ and declaring to fiscal authorities $x$ is given by

$$
I=w-x t
$$

This expression captures the fact that taxes and social security contributions are deducted from the worker's declared gross wage $x$, not from his true gross wage $w$. As income is non-stochastic, income maximization corresponds to utility maximization, given the assumption that (indirect) utility only depends on net income.

Free entry implies that firms will compete by offering to workers the package $(w, x)$ which maximizes (5) until the expected profits go to zero. Thus, the wage equation is obtained by equalling the expected profits (4) to zero,

$$
w=w(x)=y-\gamma \theta t \frac{1}{y} \frac{1}{2}(y-x)^{2} .
$$

The corresponding income for the worker is given by substituting (6) into (5)

$$
I=y-\gamma \theta t \frac{1}{y} \frac{1}{2}(y-x)^{2}-x t
$$

and the solution to the reporting decision problem is obtained by maximizing income given by (7), i.e.

$$
\max _{x \in[0, y]} \quad y-\gamma \theta t \frac{1}{y} \frac{1}{2}(y-x)^{2}-x t .
$$

The first-order condition is

$$
t-\gamma \theta t \frac{1}{y}(y-x)=0 \Leftrightarrow x=\left(1-\frac{1}{\gamma \theta}\right) y .
$$


The second-order condition is always satisfied. The boundary condition $x \leq y$ is always satisfied. Notice that full compliance (i.e. $x=y$ ) does not take place unless $\gamma \theta \rightarrow+\infty{ }^{9}$. The condition $x \geq 0$ is satisfied if and only if $\gamma \theta \geq 1$. When enforcement is very weak, so that $\gamma \theta<1$, full evasion will take place, i.e. $x=0$. To simplify the notation, the two enforcement parameters are summarized by

$$
\alpha \equiv \frac{1}{\gamma \theta} .
$$

To summarize, the solution to the reporting problem without minimum wage is given by

$$
x^{*}=\left\{\begin{array}{lll}
(1-\alpha) y & \text { if } & \alpha \leq 1 \\
0 & \text { if } & \alpha>1
\end{array} .\right.
$$

Thus, the model implies that, irrespective of the specific level of productivity, firms reveal a constant fraction of their production to the fiscal authorities. As $\frac{\partial \alpha}{\partial \gamma}<0$ and $\frac{\partial \alpha}{\partial \theta}<0$, in an interior solution, the fraction of production that is evaded decreases as enforcement improves. Substituting (9) into (7), we get the worker's income

$$
I^{*}=\left\{\begin{array}{lll}
y(1-t)+\frac{1}{2} \alpha y t & \text { if } & \alpha \leq 1 \\
y\left(1-\frac{1}{2} \frac{1}{\alpha} t\right) & \text { if } & \alpha>1
\end{array} .\right.
$$

The expected fraction of concealed production that is discovered in case of auditing is, by substituting $x=(1-\alpha) y$ into (2), $\frac{1}{2} \alpha$. Thus, for example, in an economy where $30 \%$ of the income are concealed, only $15 \%$ of the evasion are, on average, detected in case of auditing.

\section{Effects of the minimum wage}

In this section, we study what are the effects of introducing a minimum monthly wage $\varpi$, with universal coverage, in the economy described in the previous section. Workers cannot be legally employed at a wage below the minimum, in the sense that their reported gross wage cannot be below the

\footnotetext{
${ }^{9}$ In Tonin (2006a), it is shown that even with the probability of auditing depending on reported income, i.e. $\gamma=\gamma(x)$, evasion remains at all levels of income as far as $\lim _{x \rightarrow y^{-}} \gamma(x) \theta<+\infty$. This is due to the fact that as $x \rightarrow y^{-}$, the expected fine in case of auditing goes quadratically to zero, while the benefit of tax evasion goes linearly to zero.
} 
minimum. The assumption in the model is that the minimum wage is fixed on a monthly basis for full-time work and that no alternative working-time arrangements are available. However, in Tonin (2006a), the model is extended to the case where the minimum wage is fixed on an hourly basis, labour supply can vary across workers and underreporting can involve both hours of work and hourly wage. The results are qualitatively unchanged. In what follows, we focus on the case with partial evasion, i.e. $\alpha \in(0,1)^{10}$.

\subsection{Effects on the distribution}

With the introduction of a minimum wage (8) becomes

$$
\max _{x \in\{0\} \cup[\varpi, y]} y-\gamma \theta t \frac{1}{y} \frac{1}{2}(y-x)^{2}-x t .
$$

The only difference is in the choice set which shrinks from $[0, y]$ to $\{0\} \cup[\varpi, y]$. The introduction of the minimum wage divides worker-firm pairs into three categories:

1. High productivity: $y_{i}>\frac{\varpi}{1-\alpha}$

2. Intermediate productivity: $\varpi \leq y_{i} \leq \frac{\varpi}{1-\alpha}$

3. Low productivity: $y_{i}<\varpi$

Worker-firm pairs characterized by high productivity would have declared more than the minimum wage anyway, so they are unaffected by it. The minimum wage is instead a binding constraint for worker-firm pairs that would have declared less in its absence. We first analyse the case of lowproductivity workers.

\footnotetext{
${ }^{10}$ For this to be the case, we need $\gamma \theta>1$. By assumption $\theta>1$, but $\gamma$, the probability of being subject to an audit, may be low, so this condition may seem restrictive. Notice, however, that in this model, an audit is extremely ineffective. As already mentioned if, for instance, $30 \%$ of the income are evaded, during an audit on average only $15 \%$ of the evaded income are discovered. Thus, more than a full-fledged investigation, an audit should in the present set-up rather be interpreted as a routine check by the fiscal authorities, thus occurring much more frequently than a thorough inquiry.
} 
Low productivity A worker with productivity below the minimum wage, $y_{i}<\varpi$, can only work in the black market or be inactive. The possibility of a worker paying back part of his wage to the firm is thus excluded. The main results are qualitatively unaffected by this modelling choice. From (10), we get income in case of work in the black market, i.e. full evasion,

$$
I_{b m} \equiv y_{i}\left(1-t \frac{1}{2 \alpha}\right)
$$

Income in case of inactivity is assumed to be 0 . The labour market status is chosen by comparing income in the two cases, giving the following condition

$$
I_{b m}>0 \Leftrightarrow \alpha>\frac{t}{2} .
$$

Then, if $\alpha>\frac{t}{2}$, workers with productivity below the minimum wage work in the black market, otherwise they withdraw from the labour market. Thus, the prediction is that, for a given tax rate, in economies where enforcement is quite effective, i.e. $\alpha$ is low, the minimum wage pushes workers into inactivity and therefore, it has a negative impact on efficiency, as productive labour stays idle. Instead, in economies with not very effective enforcement, the minimum wage has no negative impact on efficiency as workers continue to produce in the black market. Naturally, this is true as far as going completely underground does not entail a drop in productivity.

Intermediate productivity The possibility of declaring the minimum wage and thus, participating in the formal labour market is available for worker-firm pairs whose optimal declaration in case of no minimum wage regulation is less than $\varpi$, but with productivity above $\varpi$, i.e.

$$
(1-\alpha) y_{i} \leq \varpi \leq y_{i} \Leftrightarrow \varpi \leq y_{i} \leq \frac{\varpi}{1-\alpha} .
$$

Income in case of declaring $\varpi$ is given by substituting $x=\varpi$ in $(7)$

$$
I_{m w} \equiv y_{i}(1-t)+\left(y_{i}-\varpi\right) t-t \frac{1}{\alpha y_{i}} \frac{1}{2}\left(y_{i}-\varpi\right)^{2} .
$$

Declaring a wage higher than the minimum is never optimal for this group. Moreover, as $I_{m w}>0$ for productivities satisfying (12), these workers will never go into inactivity. The choice is thus between declaring the minimum 
wage or working in the black market and declare 0 . The comparison between income in case of declaring the minimum wage and income in the black market as given by (11) gives the following condition

$$
I_{m w} \geq I_{b m} \Leftrightarrow y_{i} \geq \frac{1}{2(1-\alpha)} \varpi \equiv y_{m w} .
$$

As the choice between employment at the minimum wage and employment in the black market is only relevant for workers satisfying (12) to determine the behaviour once a minimum wage is introduced, it is necessary to position $y_{m w}$ in the interval $\left[\varpi, \frac{\varpi}{1-\alpha}\right]$. The threshold $y_{m w}$ is greater than the minimum wage if and only if $\alpha>\frac{1}{2}$, while it is always the case that $y_{m w}<\frac{\varpi}{1-\alpha}$. Thus, if the degree of underreporting is high, i.e. $\alpha>\frac{1}{2}$, the threshold $y_{m w}$ is internal to the interval defined by condition (12). This implies that some of the workers affected by the minimum wage and with productivity higher than the minimum wage prefer to decrease evasion and declare the minimum, while others prefer to go into the black market. If the degree of underreporting is instead low, i.e. $\alpha \leq \frac{1}{2}$, all workers affected by the minimum wage and with a productivity higher than the minimum wage prefer to increase compliance and declare the minimum.

The results are summarized in the below proposition.

Proposition 1 The introduction of the minimum wage in an economy with underreporting of earnings induces some workers to increase compliance by increasing declared earnings to the minimum wage level. Workers with high productivity are unaffected. Workers with productivity below the minimum wage work in the black market if enforcement is not too effective, otherwise they withdraw from the labour force.

The distribution of declared earnings $x$ before the introduction of the minimum wage is given by

$$
g_{x}(x)=\left\{\begin{array}{ll}
g\left(\frac{x}{1-\alpha}\right) & \underline{\mathrm{y}}(1-\alpha)<x<\bar{y}(1-\alpha) \\
0 & \text { otherwise }
\end{array},\right.
$$

where $g(\cdot)$ is the pdf of the productivity distribution. After the introduction 
of the minimum wage, it is given by

$$
g_{m w}(x)=\left\{\begin{array}{lll}
\int_{\underline{\mathrm{y}}}^{\varpi \max \left\{\frac{\varpi}{2(1-\alpha)}, 1\right\}} g(y) d y & \text { if } \quad x=0 \\
\int_{\varpi \max \left\{\frac{\mathrm{w}}{1-a}\right.}\left\{\frac{1}{2(1-\alpha)}, 1\right\} & g(y) d y & \text { if } \quad x=\varpi \\
g\left(\frac{x}{(1-\alpha)}\right) & \text { if } \quad \varpi<x \leq \bar{y}(1-\alpha) \\
0 & \text { otherwise }
\end{array} .\right.
$$

Thus, a "smooth" distribution of productivity is associated with a "smooth" distribution of declared earnings without a minimum wage. However, with the introduction of the minimum wage, two spikes appear at the minimum wage level and at zero. Thus, we can state the following:

Proposition 2 In a perfectly competitive labour market with underreporting of earnings, a spike at the minimum wage level appears in the distribution of declared earnings.

Figure (1) depicts declared income as a function of productivity with and without the minimum wage. Declared income when there is no tax evasion is also plotted as a reference.

\subsection{Fiscal effects}

The minimum wage divides worker-firm pairs into three categories: those declaring nothing, those declaring the minimum wage, and the unaffected, i.e. those declaring more than the minimum. Here, we first determine payments to fiscal authorities for each category. Then, we use the above analysis of the distribution of declared earnings to find out the effects of the minimum wage on fiscal revenues.

Payments to fiscal authorities Total payments, $P$, to fiscal authorities include taxes, $T$, and expected fines, $F$. For worker-firm pairs not affected by the minimum wage, these quantities are

$$
P_{1}=\left(1-\frac{\alpha}{2}\right) t y \searrow \begin{aligned}
& T_{1}=(1-\alpha) t y \\
& F_{1}=\frac{\alpha}{2} t y
\end{aligned} .
$$


Underreporting gives worker-firm pairs with relatively high productivity the opportunity to reduce the "effective"11 tax rate by a factor $\frac{\alpha}{2}$. For workerfirm pairs declaring the minimum wage, fiscal payments are given by

$$
P_{2}=t \bar{w}+t \frac{1}{2 \alpha} \frac{(y-\varpi)^{2}}{y} \searrow \begin{aligned}
& T_{2}=t \varpi \\
& F_{2}=\frac{1}{2 \alpha} \frac{(y-\varpi)^{2}}{y} t
\end{aligned} .
$$

The remaining category is represented by worker-firm pairs that are either in the black economy (when $\alpha \geq \frac{t}{2}$ ) or do not participate in the labour market (when $\alpha<\frac{t}{2}$ ). For workers in the black market, fines are the only type of payment, so that

$$
P_{3}=F_{3}=t \frac{1}{2 \alpha} y .
$$

Workers who withdraw from the labour market do not contribute to the public finances, so

$$
P_{4}=F_{4}=0 .
$$

Notice that $\frac{P_{3}}{y} \geq \frac{P_{2}}{y} \geq \frac{P_{1}}{y}$ in the relevant intervals ${ }^{12}$. Expected payments as a portion of income are highest for worker-firm pairs in the black economy and lowest for worker-firm pairs not affected by the minimum wage. Thus, considering expected total payments, it is possible to state the following:

Proposition 3 The interaction of minimum wage and underreporting transforms a nominally neutral tax system into a regressive one.

The intuition behind this result is simple: worker-firm pairs try to minimize the share of the product paid to fiscal authorities. The minimum wage is not a binding constraint for high productivity workers who manage to reduce the "effective" tax rate. For instance, if $\alpha=40 \%$, the "effective" tax rate for these workers is $80 \%$ of $t$. For workers with intermediate productivity, the minimum wage is binding. Thus, they are less "successful" in minimizing their "effective" tax rate, even if they still manage to reduce it below $t$. Low productivity workers are even more constrained, as their only choice is to work in the black market or withdraw from the labour market, and they may

\footnotetext{
${ }^{11}$ In the sense of total expected payments to fiscal authorities, including fines, over total product, i.e. $\frac{P}{y}$.

${ }^{12}$ In particular, $\frac{P_{2}}{y} \geq \frac{P_{1}}{y} \forall y, \frac{P_{3}}{y} \geq \frac{P_{1}}{y} \forall y, \frac{P_{3}}{y} \geq \frac{P_{2}}{y} \Leftrightarrow y \geq \frac{\varpi}{2(1-\alpha)}$. As only workers with productivity $y_{i} \geq \max \left(\varpi, \frac{\varpi}{2(1-a)}\right)$ will declare the minimum wage, then $\frac{P_{3}}{y} \geq \frac{P_{2}}{y}$ for the relevant interval.
} 
end up facing an "effective" tax rate above $t$. With $\alpha=40 \%$, for instance, the "effective" tax rate for these workers is indeed $125 \%$ of $t$. Figure (2) shows the effective tax rate as a function of productivity.

Effects of the minimum wage on revenues When workers with productivity below the minimum wage work in the black market, i.e. when $\alpha \geq \frac{t}{2}$, total revenues $R$ are given by

$$
\begin{aligned}
R= & \int_{0}^{\max \left(\varpi, \frac{\varpi}{2(1-a)}\right)} t \frac{1}{2 \alpha} y g(y) d y+\int_{\max \left(\varpi, \frac{\varpi}{2(1-a)}\right)}^{\frac{\varpi}{1-a}}\left[t \bar{w}+t \frac{1}{2 \alpha} \frac{(y-\varpi)^{2}}{y}\right] g(y) d y+ \\
& +\int_{\frac{\varpi}{1-a}}^{\bar{y}}\left(1-\frac{\alpha}{2}\right) \operatorname{tyg}(y) d y .
\end{aligned}
$$

The marginal worker is indifferent between being employed in the black market or declaring the minimum wage if $\alpha>\frac{1}{2}$, while he prefers not to be completely underground if $\frac{t}{2} \leq \alpha \leq \frac{1}{2}$. In the first case, the only effect of a marginal increase in the minimum wage is to extract higher payments from workers declaring it while in the second case, there is the additional effect of pushing worker-firm pairs previously in the official economy into the black market. In both cases, total revenues increase with an increase in the minimum wage, i.e.

$$
\frac{\partial R}{\partial \varpi}>0
$$

When workers with a productivity below the minimum wage withdraw from the labour market, i.e. when $\alpha<\frac{t}{2}$, there is no black market from which to extract fines, and total revenues are given by the last two terms in expression (15). Then,

$$
\frac{\partial R}{\partial \varpi}=-t \bar{w} g(\varpi)+\int_{\varpi}^{\frac{\varpi}{1-a}}\left[1-\frac{1}{\alpha} \frac{(y-\varpi)}{y}\right] \operatorname{tg}(y) d y .
$$

The first term represents the fiscal loss due to the withdrawal of workers from the labour market, the second term the higher payments by workers declaring the minimum wage. The net effect depends on the shape of the distribution. We can then state the following proposition: 
Proposition 4 When underreporting is high, revenues increase with the minimum wage. When underreporting is low, the effect of increasing the minimum wage on revenues depends on the productivity distribution.

The intuition is straightforward: maximization of workers' net income is equivalent to minimization of transfers to the government. Choice is limited to the possible declaration space $\{0\} \cup[\varpi,+\infty)$. Increasing the minimum wage shrinks the possible declaration space, so that the newly chosen compliance after the increase in the minimum wage cannot make workers better off. When the increase in the minimum wage does not have a negative impact on production, i.e. it does not "shrink the pie", this implies that the government cannot be made worse off, i.e. revenues cannot decrease. This can be counterbalanced by a decrease in revenues due to reduced total production when an increase in the minimum wage pushes low productivity workers out of the labour market.

This implies that countries where underreporting is serious because of limited enforcement capacity can use the minimum wage to boost fiscal revenues, without having to worry too much about the impact on efficiency. As enforcement improves, the minimum wage becomes a less effective fiscal instrument and efficiency issues become more prominent. However, equity issues are also at stake, as the minimum wage increases revenues by extracting more payments from low productivity workers.

The revenue boosting effect of the introduction of a minimum wage can be substantial. In Bulgaria, for instance, social security contribution payments increased by almost $20 \%$ in 2003 "[a]s a result from the registration of the labor contracts and the introduction of the minimum insurance income upon principal economic activities and qualification groups of professions, as well as from the improved economic situation" (NSSI).

\subsection{The effect of a minimum wage hike on incomes}

Here, we characterize the change in income due to a minimum wage hike for different categories of workers. Suppose that in the first period the minimum wage is $\varpi_{1}$, increasing to $\varpi_{2}>\varpi_{1}$ in the second period. The change in income due to the minimum wage hike is $\Delta I=I_{2}-I_{1}$, where $I_{t}$ is income in period $t$.

If a worker already operates in the underground market or declares earnings above $\varpi_{2}$ in the first period, then he will not change his behaviour after 
the minimum wage hike and thus, his income remains unchanged, $\Delta I=0$. A worker whose official earnings are exactly equal to the minimum wage in the first period, $\varpi_{1}$, may experience an increase in declared earnings to $\varpi_{2}$, with a corresponding income change of

$$
\Delta I=-\frac{t}{2 \alpha y}\left(\varpi_{2}-\varpi_{1}\right)\left[\varpi_{2}+\varpi_{1}-2 y(1-\alpha)\right]<0^{13} .
$$

Alternatively, his declared earnings may decrease to 0 . The income change in this case is given by

$$
\Delta I=\frac{t}{2 \alpha y} \varpi_{1}\left[\varpi_{1}-2 y(1-\alpha)\right]<0^{14,15} .
$$

In any case, the minimum wage hike results in an income decline for this type of worker. The last type of worker to analyse is the one with declared earnings between the old and new minimum wage in the first period. Also in this case may declared earning in the second period increase to $\varpi_{2}$, resulting in an income drop given by

$$
\Delta I=-\frac{t}{2 y \alpha}\left[y(1-\alpha)-\varpi_{2}\right]^{2}<0,
$$

or decrease to 0 , with the corresponding income change given by

$$
\Delta I=-\frac{y t}{2 \alpha}(1-\alpha)^{2}<0^{16}
$$

Notice that the decline in income for workers declaring $\varpi_{2}$ in the second period increases as the distance between the declared income in the first period and $\varpi_{2}$ increases. Thus, a worker who in the first period was declaring marginally above the minimum wage $\varpi_{1}$ and increases his declaration to $\varpi_{2}$ experiences a larger income decline than a worker also declaring $\varpi_{2}$ in the second period, but whose declared income in the first period was higher. The

\footnotetext{
${ }^{13}$ This is due to the fact that workers in this situation have productivity $y_{i}$ s.t. $(1-\alpha) y_{i} \leq \varpi_{1}<\varpi_{2}$.

${ }^{14}$ This is due to the fact that workers in this situation have productivity $y_{i}$ s.t. $\left\{\begin{array}{ll}y_{i}>\varpi_{1} & \text { if } \quad \alpha \leq \frac{1}{2} \\ y_{i}>\frac{\varpi_{1}}{2(1-\alpha)} & \text { if } \quad \alpha>\frac{1}{2}\end{array}\right.$.

${ }^{15}$ This assumes that workers go underground. If $\alpha<\frac{t}{2}$, so that workers withdraw from the labour market, the decline in income is obvious.

${ }^{16}$ See previous note.
} 
income decline is even larger for workers who declared the minimum wage in the first period.

The model thus predicts the following:

Proposition $5 \quad$ 1. As a result of a minimum wage hike, workers whose declared earnings before the hike are between the old and the new minimum wage experience a decline in income. Other workers are unaffected.

2. For those workers declaring the new minimum wage after the hike, the decline in income increases with the distance between the new minimum wage and the declared income before the hike.

The intuition behind these results is similar to that behind the previous proposition. Increasing the minimum wage effectively shrinks the choice set of workers declaring in the previous period between the new and the old minimum wage, making them worse-off.

This prediction of the model will be tested in section 6 using the massive minimum wage hike that took place in Hungary in 2001 as a natural experiment. A difference-in-difference approach is used. The first part of the proposition will be tested by using a "dummy treatment", identifying workers declaring an amount between the new and the old minimum wage before the hike. The second part of the proposition will be tested by using a "continuous treatment", where the distance between the new minimum wage and declared earnings before the hike is used to measure the intensity of treatment.

\section{Underground economy and minimum wage spike}

Both the size of the spike at the minimum wage and the size of the underground economy relative to the economy as a whole are determined by the interplay of the productivity distribution, the fiscal enforcement parameters as summarized by $\alpha$, and the minimum wage, $\varpi$. In this section, we study

the link between the size of the underground economy and the size of the spike. 
The spike at the minimum wage The size of the spike at the minimum wage is given by

$$
S=\int_{\max \left(\frac{1}{2(1-\alpha)} \varpi, \varpi\right)}^{\frac{\varpi}{1-a}} g(y) d y .
$$

A decrease in enforcement parameters, i.e. an increase in $\alpha$, induces the minimum wage to be declared by some workers previously declaring more, thereby increasing the size of the spike. If enforcement is sufficiently weak, i.e. if $\frac{1}{2}<\alpha<1$, an additional effect plays a role, as some workers previously declaring the minimum wage prefer to go into the black economy, thus reducing the size of the spike. In this case

$$
\frac{\partial S}{\partial \alpha}>0 \Leftrightarrow g\left(\frac{\varpi}{1-a}\right)>\frac{1}{2} g\left(\frac{\varpi}{2(1-a)}\right) .
$$

Assuming that the distribution of productivity is single peaked, the above condition is satisfied if the minimum wage is binding for workers with productivity lower than the mode. If this is the case, the spike is always increasing as $\alpha$ increases.

The effect on the size of the spike of a marginal increase in the minimum wage depends on the interplay between two effects: as $\varpi$ increases, some workers previously declaring the minimum wage are pushed out of the formal labour market, thus decreasing the size of the spike, while some, previously declaring more, declare the minimum wage, thus increasing the size of the spike. Given $\alpha$, the condition for the size of the spike to increase as the minimum wage increases is

$$
\frac{\partial S}{\partial \varpi}>0 \Leftrightarrow g\left(\frac{\varpi}{1-a}\right)>g(\varpi) \max \left(1-a, \frac{1}{2}\right) .
$$

Also in this case a single peaked productivity distribution and a minimum wage binding for workers with productivity lower than the mode are sufficient conditions for the spike to increase with the minimum wage. ${ }^{17}$

\footnotetext{
${ }^{17}$ The analysis can also be conducted in terms of the size of the spike, relative to the size of the officially employed workforce, where the latter is given by:

$$
L=\int_{\max \left(\frac{1}{2(1-\alpha)} \varpi, \varpi\right)}^{\bar{y}} g(y) d y .
$$

The conditions for the spike relative to the officially employed workforce, $\frac{S}{L}$, to increase with $\alpha$ and $\varpi$ are looser than those for $S$, as the size of the officially employed workforce decreases with $\alpha$ and $\varpi$.
} 
The informal economy When workers with a productivity below the minimum wage work in the black market, i.e. when $\alpha \geq \frac{t}{2}$, the size of the underground economy ${ }^{18}$ is given by:

$$
U=\underbrace{\int_{\underline{\mathrm{y}}}^{\max \left(\frac{1}{2(1-\alpha)} \varpi, \varpi\right)} y g(y) d y}_{\text {black economy }}+\underbrace{\int_{\max \left(\frac{1}{2(1-\alpha)} \varpi, \varpi\right)}^{\frac{\varpi}{1-a}}(y-\varpi) g(y) d y+\alpha \int_{\frac{\varpi}{1-a}}^{\bar{y}} y g(y) d y}_{\text {underreporting }}
$$

A decrease in enforcement, i.e. an increase in $\alpha$, increases the size of the informal economy as workers unaffected by the minimum wage evade more. Moreover, when enforcement is already low, i.e. $\frac{1}{2}<\alpha<1$, some workers previously declaring the minimum wage go into the black economy, thereby further increasing informality.

An increase in the minimum wage pushes some workers previously declaring the minimum wage into the black economy, thus increasing informality, but also forces workers continuing to declare the minimum to declare more of their true income, thus reducing informality. Which effect prevails depends on the shape of the productivity distribution.

When workers with productivity below the minimum wage withdraw from the labour market; i.e. when $\alpha<\frac{t}{2}$, there is no black market, thus the size of the underground economy is given by the last two terms in expression (16). Also in this case a decrease in enforcement, i.e. an increase in $\alpha$, increases the size of the informal economy as workers unaffected by the minimum wage evade more ${ }^{19}$. The absolute size of the informal economy decreases with an increase in the minimum wage, as workers declaring the minimum increase their compliance. However, in this case, an increase in the minimum

\footnotetext{
${ }^{18}$ The analysis is done on the size of the informal economy in absolute terms, $U$. The size of the informal economy relative to the economy as a whole, $\frac{U}{Y}$, or relative to the size of the formal economy, $\frac{U}{Y-U}$, are also of interest. When $\alpha \geq \frac{t}{2}$, the size of the economy is given by $Y=\int_{\underline{y}}^{\bar{y}} y g(y) d y$ and does not depend on $\alpha$ or $\varpi$. Thus, the derivatives of $U, \frac{U}{Y}$, $\frac{U}{Y-U}$ w.r.t. $\alpha$ and $\varpi$ all have the same sign.

${ }^{19}$ There is a discontinuity in the size of the informal economy at $\alpha=\frac{t}{2}$. When enforcement parameters decrease (i.e. $\alpha$ increases), the size of the informal economy jumps up discretely as workers previously withdrawn from the labour market enter into the black market. This jump goes in the same direction as the derivative, so we can state that the size of the informal economy always increases as enforcement decreases. The same is true if we consider the size of the informal economy relative to the whole economy, $\frac{U}{Y}$, or relative to the formal economy, $\frac{U}{Y-U}$.
} 
wage reduces the size of the economy, that is given by $Y=\int_{\varpi}^{\bar{y}} y g(y) d y$. The effect of an increase in the minimum wage on the size of the informal economy relative to the economy as a whole, $\frac{U}{Y}$, or relative to the formal economy, $\frac{U}{Y-U}$, is ambiguous, as it depends on the shape of the productivity distribution.

To summarize:

Proposition 6 1. When enforcement decreases, the size of the informal economy increases, both in absolute terms or relative to the formal economy. Sufficient conditions for the size of the spike at the minimum wage to increase when enforcement decreases are a single peaked productivity distribution combined with a minimum wage binding for workers with productivity lower than the mode or a not too weak enforcement.

2. The effect of an increase in the minimum wage on the size of the informal economy relative to the formal economy is ambiguous. A sufficient condition for the size of the spike at the minimum wage to increase when the minimum wage increases is a single peaked productivity distribution combined with a minimum wage binding for workers with productivity lower than the mode.

Thus, under mild conditions, the common dependence on $\alpha$ should induce a positive correlation between the spike at the minimum wage and the size of the informal economy. Some evidence on this correlation is presented in section 7 .

\section{The empirical effect of a minimum wage hike on incomes}

In this section, we test Proposition 5 about the decline in true income for workers affected by a minimum wage hike. The massive minimum wage increase that took place in Hungary in 2001 is used as a natural experiment. Hungarian microdata from the household budget survey for the years 19992001 are used. The method proposed by Pissarides and Weber (1989) is adapted to a panel framework by comparing the change in food consumption for households affected by the minimum wage hike and similar but unaffected households. 
First, the Hungarian context is analysed, looking at the fiscal environment, the relevance of the informal economy, and the minimum wage. Then, the statistical framework is outlined. Finally, the results are presented.

\subsection{The Hungarian context}

In Hungary, taxation on labour is heavy, also for low paid workers. In the period 2000-2002, the tax wedge on a single person without children earning $2 / 3$ of the average production wage was at around $46 \%$, one of the highest in Europe, with marginal rates above 55\% (OECD, 2001 and 2002.) The degree of informality is also high, with evidence of there being underreporting of earnings. For instance, $56 \%$ of the households interviewed in a survey claim that in their neighbourhood, employers are declaring the minimum wage to the tax authority, while unofficially paying additional wages (ECONSTAT, 1999.)

The statutory minimum wage ${ }^{20}$ was significantly increased from 25,500 HUF in 2000 (98 EUR or 90 USD using the average exchange rate for the corresponding year) to 40,000 HUF in 2001 (156 EUR, 140 USD.) As a consequence, the corresponding total monthly payments to the fiscal authorities (PIT and SSC) increased by around 9,000 HUF (36 EUR, 32 USD. $)^{21}$ It is interesting to notice how the hike was decided one-sidedly by the centre-right government, against the opposition of the largest trade union federation. The impact of the minimum wage hike clearly appears in figure (3). The share of full-time employees paid $95 \%-105 \%$ of the minimum wage in firms employing more than five workers jumped from 5\% in 2000 to $12.1 \%$ in 2001 (Kertesi and Köllö, 2003.)

In their study on the labour market impact of the 2001 minimum wage rise, Kertesi and Köllö (2003) find a high level of compliance with the minimum wage regulation, with only a minor spillover on the wage distribution. They compare the job loss risk of workers earning $90-110 \%$ of the minimum

\footnotetext{
${ }^{20}$ The statutory minimum wage covers all employment contracts and relates to gross monthly earnings net of overtime pay, shift pay and bonuses for full-time employment. For part-timers, it is proportionally lower, but part-timers only account for a small portion of all employees (3.6\% in 2001-2002.) According to the Hungarian UI Exit to Job Survey, $64.7 \%$ of the low-wage UI recipients who found a job in April 2001 received a fixed salary, $33.8 \%$ were paid an hourly wage and the remaining $1.5 \%$ concluded a business contract with the employer (Kertesi and Köllö, 2003.)

${ }^{21}$ Additional details can be found in Tonin (2006b.)
} 
wage in 2001, the treatment group, to that of workers earning 110-125\%, the control group, and find a small but significant effect on the quarterly outflow into unemployment ${ }^{22}$. They find no effect on the flow from employment to non-participation. They also find a 7-8\% drop in the job finding probability of low-wage unemployed, defined as those receiving lower than average unemployment benefits, relative to the unskilled as a whole, defined as those with less than secondary education. The conclusion of their study is that "despite the brutal price shock the immediate effect did not seem dramatic".

\subsection{The statistical framework}

Reported income, $x_{i, t}$, is observed for household $i$ at time $t$. Reported income is related to true income, $I_{i, t}$, by the following relationship

$$
x_{i, t}=k_{i, t} I_{i, t}
$$

where $0 \leq k_{i, t} \leq 1$

True income is related to permanent income, $I_{i, t}^{P}$, by the following relationship

$$
I_{i, t}=p_{i, t} I_{i, t}^{P},
$$

where $p_{i, t} \geq 0$.

By combining (17) and (18) and taking logs, we can write permanent income as a function of reported income:

$$
\ln I_{i, t}^{P}=\ln x_{i, t}-\ln k_{i, t}-\ln p_{i, t} .
$$

The relationship between food consumption and permanent income is assumed to be

$$
\ln c_{i, t}=Z_{i, t} \alpha+\beta \ln I_{i, t}^{P}+\varepsilon_{i, t},
$$

where $Z_{i, t}$ is a row vector of household characteristics. The use of food consumption is standard in the literature estimating tax evasion by using household budget survey data. This is due to the fact that food consumption is more precisely recorded than consumption of other types of goods over the

\footnotetext{
${ }^{22}$ For a 25 -year old male with five years of tenure, for instance, the estimated quarterly flow is $0.243 \%$ for the treated and $0.119 \%$ for the control group. At average age and tenure of the control group (40, 7.33), the figures are $0.0168 \%$ for the treated and $0.0068 \%$ for the control group. The average age and tenure of the treatment group are not very different at 39.2 and 6.67 , respectively.
} 
limited time period in which the survey is conducted. Substituting (19) into (20), we can express consumption as a function of reported income

$$
\ln c_{i, t}=Z_{i, t} \alpha+\beta \ln x_{i, t}-\beta \ln k_{i, t}-\beta \ln p_{i, t}+\varepsilon_{i, t},
$$

and taking first differences we get

$$
\Delta \ln c_{i, t}=\Delta Z_{i, t} \alpha+\beta \Delta \ln x_{i, t}-\beta \Delta \ln k_{i, t}-\beta \Delta \ln p_{i, t}+\Delta \varepsilon_{i, t} .
$$

As seen in section 4.3, the theory indicates that as a result of a minimum wage hike, workers whose declared earnings before the hike are between the old and the new minimum wage experience a decline in income, while other workers are unaffected. Thus, for the former group of workers, we have

$$
\Delta \ln I_{i, t}=\Delta \ln x_{i, t}-\Delta \ln k_{i, t}<0
$$

In particular, for workers whose official earnings increase to the new minimum after the hike, there is an increase in their compliance with the fiscal regulation, while workers unaffected by the minimum wage hike do not experience a change in their ability to underreport. Thus, labelling the former group as "treated", we have

$$
-\Delta \ln k_{i, t}\left\{\begin{array}{ll}
<0 & \text { for the "treatment group" } \\
=0 & \text { for the "control group" }
\end{array} .\right.
$$

To identify the shock to the "underreporting technology" due to the minimum wage hike, i.e. $-\Delta \ln k_{i, t}$, we use a difference-in-difference approach. The change in food consumption for households that were affected by the minimum wage hike is contrasted to the change in food consumption for similar but unaffected households. As $\Delta \ln p_{i, t}$ is unobserved, particular care must be taken not to confound the shock to the ability to underreport with other shocks to permanent income related to the minimum wage hike due, for instance, to increased labour market risk.

Specification The basic specification is the following

$$
\Delta c_{i}=\alpha+\gamma * M_{i}+\beta * T R E A T_{i}+\Delta \varepsilon_{i}
$$

where $\Delta c_{i}$ is the change in food consumption for household $i$ in two consecutive years. $M_{i}$ is a set of dummies allowing for different trends depending on 
the months in which the household is surveyed in two consecutive years. The seasonality displayed by food prices makes it important to compare households that were interviewed in exactly the same month in both years. The exact definition of this and the other variables is provided in the Appendix. The coefficient of interest is $\beta$. The exact definition of $T R E A T_{i}$ is provided in what follows. Regressions including additional controls like the change in household income or geographical dummies are also run. The reason for preferring a specification in levels to one in logs is that the shock to underreporting is not proportional to income but is absolute. According to the model, every worker declaring the minimum wage in 2000 and then increasing his declaration to the new minimum in 2001 experiences a decline in his income of around 9,000 HUF, irrespective of differences in the income level that may arise from the availability of other sources of income or heterogeneity in the degree of underreporting.

Data and sample The data are from the Hungarian Household Budget Survey Rotation Panel ${ }^{23}$. The sample consists of around 10,000 households. One-third of the sample is rotated in each year. The two-year panels of interest for this study, i.e. 1999-2000 and 2000-2001, contain slightly more than 3,500 households. Notice that households interviewed from 1999 till 2001 appear in both panels, so that around half of the sample is the same in the two panels. The population of interest is considerably reduced by the fact that all adults are retirees in around $40 \%$ of the households.

More information about the way the survey is conducted is available in the Appendix. It is worth underlining that surveyors are expected to collect the income data used in this analysis from documentation like tax return sheet or tax certification of employer, whenever it is possible. This makes it more likely that income in the survey corresponds to income reported to the fiscal authorities more than to the, possibly different, true income.

The distribution of earnings in the dataset (see figure 4) clearly presents a spike at the minimum wage level, corresponding to $4-5 \%$ in $1999-2000$ and increasing to around $14 \%$ in 2001 . These figures are consistent with LFS data and underline the relevance of the minimum wage hike. Table 1 summarizes

\footnotetext{
${ }^{23}$ The Hungarian Household Budget Survey Rotation Panel is created by the Institute of Economics, Hungarian Academy of Sciences from the original HHBS of the Hungarian Central Statistical Office. The data set is work in progress. Although the IE made every effort to clean the data, it cannot be held liable for any remaining errors.
} 
the labour market status and flows for the whole sample.

\subsection{Empirical implementation}

A household is considered as treated if at least one of its members has been affected by the minimum wage hike. Two different methods are used to single out these individuals. In the first case, individuals employed in 2000 at a wage between the minimum wage in 2000 and the will-be minimum wage in 2001 are selected. The treatment group is thus only defined on basis of pre-treatment characteristics. In the second case, an additional requirement is imposed: being employed in 2001 at the minimum wage. The reported earnings of these employees are thus actually pushed up by the policy intervention, while in the former case, they were only potentially pushed up. For this reason, the two cases are labelled "actual" and "potential". In both instances, the variable "treatment" is defined as the number of household members conforming to the above mentioned criteria. An alternative definition of treatment is explored for the "actual" case. Instead of simply counting their number, the difference between the minimum wage in 2001 and earnings in 2000 is summed up for all members of the household affected by the hike. The aim of this continuous measure is to capture the intensity of treatment. This definition of treatment is labelled "continuous" as opposed to the "dummy" treatment previously described.

Households in the control group are defined on basis of the presence among their members of individuals earning somewhat more than the 2001 minimum wage. To check for the validity of the control group, a "placebo test" is conducted where the absence of a treatment effect in the pre-policy period is ascertained. This is done by looking at changes in food consumption in the period 1999-2000. Sample size considerations restrict this analysis to the "potential" treatment case.

To ensure comparability, the analysis is always restricted to households that keep a constant composition and whose income is within certain limits. Moreover, to avoid confounding an increase in labour market risk with an increase in compliance with fiscal regulation, only employees with stable positions are considered. The precise definitions of treatment and control groups are provided in what follows.

Potential treatment In this section, the analysis is done on the two panels covering the years 1999-2000 and 2000-2001, respectively. For each two-year 
panel, only households that kept a constant composition in the period and that had positive net income below 200,000 HUF in both years are considered. Moreover, we consider only households where at least one member has been employed for the whole period and whose wage in 2000 is between the minimum wage in 2000 and 200\% (150\%) of the minimum wage in 2001. The sample is restricted in this way to ensure comparability between the treatment and control groups.

Definition of treatment Private sector employees who have been employed for the whole period and who in the year 2000 earns a wage between the minimum wage in the year 2000 (25,500 HUF) and the minimum wage in the year 2001 (40,000 HUF) are considered to be treated. The variable $T R E A T_{i}$ contains the total number of members of household $i$ classified as treated.

Descriptive analysis The treatment and the control group are not ex ante identical along all dimensions. For instance, the mean total net income and income from the main activity at the household level are higher for the treatment than for the control group (see table 2a.), with the notable exception of the smallest control group in the post-treatment period. In this case, mean total net income does not differ significantly from the treatment group, while mean expenditures on food do. However, the considerable overlap in the distribution of household total net income for the treatment and control groups (see figure 8) indicates that the two groups are not too heterogeneous. The same conclusion emerges by comparing the estimated relationship between market food consumption and household total net income for treatment and control groups (see figures 6 and 7.) The estimated Engel curves are indeed quite overlapping in the pre-treatment period.

Results When the 2000-2001 panel is used, the coefficient of the treatment variable is, as predicted, always negative and significant whenever the larger control group is used. When the smaller control group is used, significance is not always achieved (see table 2b.) Besides the basic specification described in (22), regressions including the change in household income, the change in home production of food, the change and level of household income, employee characteristics and geographical dummies are also run. 
The validity of the control group is confirmed by the fact that the treatment is never significant in the "placebo test", when the analysis is done using the pre-treatment panel, 1999-2000 (see table 2c.) The change in food consumption does not differ between the treatment and the control group in the pre-policy period, i.e. before the minimum wage hike. After the policy has been implemented, however, the change in food consumption is significantly lower for treated households. The magnitude of the coefficient is also reasonable. Gross reported earnings by "treated" employees on average increased by around 15,000 HUF. According to the model, this should translate into a drop in true income of more than half that quantity, due to increased fiscal payments ${ }^{24}$. Considering that around a quarter of the income is spent on food consumption, a negative coefficient around 1,500-2,000 HUF is reasonable.

Actual treatment In this case, only the 2000-2001 panel is used. To ensure comparability, also in this case do we only keep in the sample households that kept a constant composition in the period and with a positive net income below 200,000 HUF in both years. Moreover, we only select households with at least one member employed during the whole of 2001 at a wage between $90 \%$ and $200 \%$ (150\%) of the minimum wage in 2001 .

Definition of treatment An employee must satisfy two criteria to be considered treated. First, he should work for the whole of 2001 in the private sector and earn a wage around the minimum wage in that year (90\%-110\% are the thresholds considered.) Moreover, he should have been employed in 2000 at a wage between the old and the new minimum wage (the thresholds are $90 \%$ of the minimum wage in 2000 and $110 \%$ of the minimum wage in 2001.) In the "dummy treatment", the variable $T R E A T_{i}$ contains the number of household members belonging to this category. In the "continuous treatment", the variable TREAT is the sum within household $i$ of the difference between the minimum wage in 2001 and the wage in 2000 for the same people as in the "dummy treatment" with the difference that $100 \%$ and not $110 \%$ of the minimum wage in 2001 are used as the upper bound.

\footnotetext{
${ }^{24}$ Social security contributions rate: $48.5 \%$. Personal income tax marginal rate: $8 \%$ until 30,000 HUF, $18 \%$ thereafter. Total: $56.5 \%$ until 30,000 HUF, $66.5 \%$ thereafter. The decrease in expected fines due to increased compliance should be accounted for.
} 
Descriptive analysis The descriptive analysis is limited to the definitions used in the "dummy treatment".

As previously, mean expenditures on food, total net income and income from the main activity at the household level differ between treatment and control groups (see table 3a.) However, the estimated distribution of household total net income (see figure 8) shows a significant overlap between treatment and control groups and the estimate of the relationship between market food consumption and household total net income (see figure 9) shows basically identical Engel curves for treatment and control groups in the pretreatment period. Thus, the two groups are not too dissimilar.

Results The results confirm the previous analysis. The coefficient of interest is always negative, both when using the "dummy treatment" (see table 3b) and the "continuous treatment" (table 3c.) In each case, regressions controlling for changes in home production of food, changes in household income, the level and change of household income as well as employee characteristics and geographical dummies are included. Significance is almost always achieved when using the "dummy treatment" and the magnitude of the coefficient in the range 1,000-1,500 HUF is reasonable, considering that in this case, earnings by "treated" employees on average increased by around 9,000 HUF $^{25}$. In "continuous treatment", significance is mainly achieved when additional controls beside month dummies are included. Also in this case is the magnitude of the coefficient reasonable ${ }^{26}$.

Including in the analysis only households with a net income between 50,000 HUF and 150,000 HUF in both years (results not reported) generally makes coefficients greater in absolute value. Significance improves in the "continuous treatment" case, in particular when only month dummies are used as additional controls, while the outcome is more mixed in the "dummy treatment" case.

The negative impact on the change in food consumption of being treated has been confirmed by the use of different definitions of treatment and different specifications. The use of employees with stable working positions in

\footnotetext{
${ }^{25}$ The reasoning is the same as in the previous case. An increase in reported income translates, according to the model, into a drop in true income, due to increased fiscal payments, corresponding to more than half that quantity. Moreover, also in this case around one quarter of income is spent in food.

${ }^{26}$ See the previous note. Having earnings pushed up by the minimum wage increase by 1 HUF implies, according to the model, a decrease in true income of around 0.5 HUF.
} 
the definition of treatment makes it unlikely that the effect is due to adverse labour market effects of the minimum wage hike which, anyhow, other studies have found to be rather limited. Thus, there is support for the implication of the model that the minimum wage may actually squeeze more fiscal revenues from affected households.

\section{$7 \quad$ Evidence on underground economy and min- imum wage spike}

As stated in Proposition 6, a prediction of the model is that enforcement parameters (as summarized by $\alpha$ ) should induce a positive correlation between the spike at the minimum wage and the size of the informal economy relative to the formal economy. In this section, some supporting evidence is presented.

The two figures below present the relationship of the spike at the minimum wage $^{27}$ with the size of the informal economy relative to the formal economy $^{28}$ and the ratio of the minimum wage to the average wage ${ }^{29}$ (in what follows, this measure is indicated as the Kaitz index.) The countries included are all countries for which Eurostat reports data on the minimum wage spike and Schneider (2005) reports estimates of the informal economy. The sample includes 16 European countries and the US. Ten of the European countries are Central and Eastern European, where statutory minimum wage arrangements are common.

\footnotetext{
${ }^{27}$ Proportion of full-time employees with earnings exactly equal to the monthly minimum wage (source: Eurostat). Notice that the data collected by Eurostat are obtained from administrative sources. For data points indicated with a triangle, the definition is different: part-time workers are included (France, Spain), minimum wage is fixed on an hourly basis (France, Ireland, UK, USA), earnings below the minimum wage are also included (UK, USA). See Eurostat (2004) for details.

${ }^{28}$ Informal economy as \% of official GDP (source: Schneider 2005).

${ }^{29}$ Minimum monthly wage as a proportion of average monthly earnings in industry and services (source: Eurostat). For France, the figure has been calculated by the author dividing the hourly gross wage by the average gross hourly wage for a full-time employee in industry, trade and services (data source: INSEE.)
} 


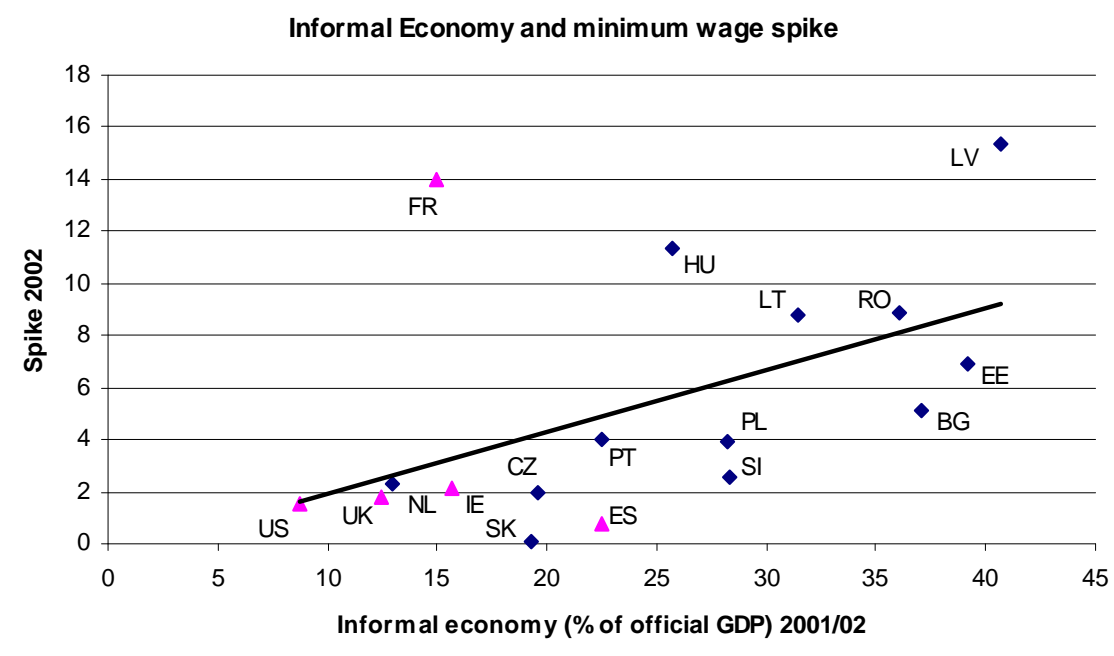

Sources: informal economy: Schneider (2005); spike: Eurostat

A positive correlation clearly appears between the size of the spike at the minimum wage level and the estimated size of the informal economy. As mentioned in the introduction, other mechanisms have been proposed to explain the existence of a spike at the minimum wage level and one natural "culprit" for a high spike would be a minimum wage "biting" deeply into the wage distribution. However, no clear relationship appears between a measure of this "bite", the Kaitz index, and the size of the spike.

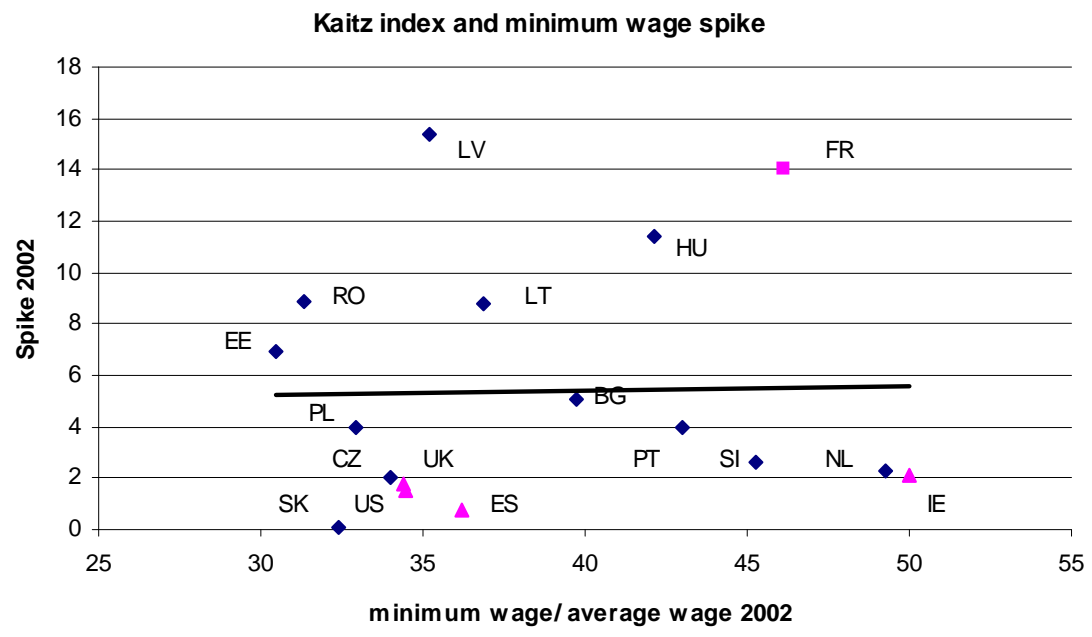

Source: Eurostat, except France - Kaitz Index: own calculations 
Regression analysis (see table 4) confirms that the positive relationship between the spike and the informal economy is not driven by a high minimum wage resulting in both a high spike and a sizeable informal economy. Regressing the size of the spike on the size of the informal economy and the Kaitz index, the former is significant, while the latter is not. The model suggests that the positive correlation between the size of the spike and the size of the informal economy is instead driven by the common dependence on enforcement parameters. The regression implies that a 1\% increase in the size of the informal economy is associated with a $0.28 \%$ increase in the share of employees earning the minimum wage.

\section{Conclusions}

The paper develops a tractable model of underreporting of earnings by employed labour and works out the implications of introducing minimum wage regulation in such an environment.

A contribution of the paper to the literature on tax evasion is to show that imperfect detection alone is able to generate an internal solution to the tax evasion decision, even with the fixed probability of an audit and risk neutrality by the agent subject to this.

The interaction between tax evasion and minimum wage gives rise to a spike at the minimum wage level. This is a mechanism that has never been proposed in the literature, that works in a perfectly competitive labour market and that can account for the double digit spike present in some countries $^{30}$.

In addition, the model contributes to the policy discussion on minimum wage in countries where underreporting of earnings is a relevant phenomenon. In particular, it is shown that introducing or increasing the minimum wage can boost fiscal revenues. The discussion of the fiscal impact of the minimum wage has usually focused on the expenditure side. The role of the state as an employer or the fact that in some countries social benefits are indexed to the minimum wage are two reasons why a higher minimum wage could worsen the fiscal balance. This paper claims that this may not be the case, if the effect on revenues is sufficiently large to counterbalance the higher spending. The boost in revenues is due to extracting more resources from the lower end of the productivity distribution. This may be desirable as there is some

\footnotetext{
${ }^{30} \mathrm{~A}$ simple numerical exercise showing this can be found in Tonin (2006a.)
} 
evidence that tax evasion among employees is concentrated at the low end of the income distribution (see section 2.) On the other hand, if the aim of the minimum wage hike is to boost income for those affected, it could have opposite consequences. An increase in reported income could actually correspond to a decrease in true income, unless the minimum wage hike is accompanied by a decrease in fiscal pressure for minimum wage earners. The elimination of personal income tax for minimum wage workers undertaken by the newly elected centre-left government in Hungary in 2002 may be due to this kind of considerations.

The model also makes a new prediction about the correlation between the size of the spike at the minimum wage level and the size of the informal economy that finds support in the data.

The optimal auditing strategy by a tax authority in case it possesses an imperfect detection technology is the subject of ongoing research.

\section{References}

[1] Acemoglu, D. Good jobs versus bad jobs. 2001. Journal of Labor Economics, vol. 19, pp. 1-21.

[2] Andreoni, J., Erard, B., Feinstein, J. 1998. Tax compliance. Journal of Economic Literature, vol. 36, pp. 818-860.

[3] Besim, M. and Jenkins, G.P. 2005. Tax compliance: when do employees behave like the self-employed. Applied Economics, vol. 37, pp. 12011208.

[4] Boeri, T. and Garibaldi, P. 2005. Shadow Sorting, forthcoming in Pissarides, C. and Frenkel, J. (eds.) NBER International Seminar on Macroeconomics 2005, MIT Press.

[5] Brown, C. 1999. Minimum wages, employment, and the distribution of income. Handbook of Labor Economics, vol. 3.

[6] Card, D., Krueger, A. 1995. Myth and measurement. Princeton University Press.

[7] Cowell, F. 1985. Tax evasion with labour income. Journal of Public Economics, vol. 26, pp. 19-34. 
[8] Dickens, R., Manning, A. 2004. Spikes and spill-overs: the impact of the national minimum wage on the wage distribution in a low-wage sector. Economic Journal, vol. 114, pp. 95-101.

[9] DiNardo, J., Fortin, N., Lemieux, T. 1996. Labor market institutions and the distribution of wages, 1973-1992: a semiprametric approach. Econometrica, vol. 64(5), pp. 1001-1044.

[10] Draca, M., Machin, S., and Van Reenen, J. 2006. Minimum wage and firm profitability. IZA DP 1913.

[11] ECONSTAT. 1999. A lakosság részvétele a rejtett gazdaságban. Időszaki Közlemények 18.

[12] Erard, B. 1997. Self-selection with measurement errors. A microeconometric analysis of the decision to seek tax assistance and its implications for tax compliance. Journal of Econometrics, vol. 81, pp. 319-356.

[13] Eurostat. 2004. News release 85/2004.

[14] Feinstein, J. 1991. An econometric analysis of income tax evasion and its detection. RAND Journal of Economics, vol. 22, pp. 14-35.

[15] Fiorio, C., and D'Amuri, F. 2005. Workers' tax evasion in Italy. Giornale degli Economisti e Annali di Economia, vol. 64 n. 2/3.

[16] Fugazza, M., Jacques, J. 2003. Labor market institutions, taxation and the underground economy, Journal of Public Economics vol. 88, pp. 395-418.

[17] Gorodnichenko, Y. and Sabirianova Peter, K. 2006. Public Sector Pay and Corruption: Measuring Bribery from Micro Data. IZA DP 1987.

[18] Kertesi, G. and Köllő, J. 2003. Fighting "low equilibria" by doubling the minimum wage? Hungary's experiment. IZA DP No. 970.

[19] Klepper, S., Nagin, D. 1989. The anatomy of tax evasion. Journal of Law, Economics, and Organization, vol. 5(1), pp. 1-24.

[20] Kolm, A. and Nielsen, S.B. 2005. Under-Reporting of Income and Labor Market Performance. WP 2005:5, Stockholm University. 
[21] Lemieux, T., Fortin, B. and Frechette, P. 1994. The effect of taxes on labor supply in the underground economy. American Economic Review, vol. 84 , no. 1 , pp. 231-54.

[22] Lemos, S. 2006. A Survey of the Effects of the Minimum Wage on Prices. Forthcoming Journal of Economic Surveys.

[23] Lyssiotou, P., Pashardes, P. and Stengos, T. 2004. Estimates of the black economy based on consumer demand approaches. The Economic Journal, vol.114, pp.622-640.

[24] NSSI. Undated. Report from Jordan Hristoskov - governor of the National Social Security Institute, concerning of the State Social Security Budget, 2003. (www.noi.bg).

[25] OECD. 2001. Taxing wages 2000-2001. OECD.

[26] OECD. 2002. Taxing wages 2001-2002. OECD.

[27] OECD. 2003. Labour market and social policies in the Baltic countries. (Paris, OECD.)

[28] OECD. 2004. Employment Outlook. (Paris, OECD.)

[29] Petrova, A. 2005. Wages: On the Payroll or Under the Table? (Public Opinion Foundation, www.fom.ru)

[30] Pissarides, C and Weber, G. 1989. An expenditure-based estimate of Britain's black economy. Journal of Public Economics, vol. 39, pp. 1732 .

[31] Renooy, P., Ivarsson, S., van der Wusten-Gritsai, O. and Meijer, R. 2004. Undeclared work in an enlarged Union. Report for the European Commission.

[32] Sandmo, A. 1981. Income tax evasion, labour supply, and the equityefficiency tradeoff. Journal of Public Economics, vol. 16, pp. 265-288.

[33] Schneider, F. 2005. Shadow economies of 145 countries all over the world: estimation results over the period 1999 to 2003. Working Paper. 
[34] Schneider, F., Enste, Dominik. 2000. Shadow economies: size, causes, and consequences. Journal of Economic Literature, vol. 38(1), pp. 77114 .

[35] Schneider, F., Enste, Dominik. 2003. The shadow economy: an international survey. Cambridge University Press.

[36] Simon, K.I., Kaestner, R. 2004. Do minimum wages affect non-wage job attributes? Evidence on fringe benefits. Industrial and Labor Relations Review, vol. 58, pp. 52-70.

[37] Slemrod, J., Yitzhaki, S. 2002. Tax avoidance, evasion, and administration. In: Auerbach, A., Feldstein, M. (eds.) Handbook of Public Economics, vol. 3. Elsevier Science.

[38] Tedds, L. 2005. Nonparametric expenditure-based estimation of income under-reporting and the underground economy, Working Paper, McMaster University.

[39] Tomev, L. 2004. Thematic feature - industrial relations and undeclared work. EIRO www.eiro.eurofound.eu.int.

[40] Tonin, M. 2006a. The effects of the minimum wage in an economy with tax evasion. IIES Seminar Paper 747.

[41] Tonin, M. 2006b. Did the minimum wage increase in 2001 reduce tax evasion in Hungary? mimeo.

[42] Yaniv, G. 1992. Collaborated employee-employer tax evasion. Public Finance/ Finances Publiques, vol. 47(2), pp. 312-321.

[43] World Bank. 2005. Enhancing Job Opportunities: Eastern Europe and the Former Soviet Union. (Washington, World Bank.)

[44]_. 2006. Turkey. Country Economic Memorandum. (Washington, World Bank.) 


\section{Appendix}

The survey A household consists of persons forming a common income and/or consumption unit, completely or partly sharing the current costs of living

The selection of the sample is done by multistrata method using census data. In a given month during the year, households keep a diary registering income and expenditures during the month and "general household characteristics" containing demographic, employment and housing data.

In subsequent interviews, data on personal incomes, family income, stock of consumer durables, expenditures of significant value, are retrospectively collected for the year as a whole.

\section{Main variables and categories}

- "Households with constant family structure" are households where the same individuals are present for the relevant period. Restricting the analysis to this type of household reduces the sample in the panel 19992000 from 3581 to 3181, with a loss of 400 households, for the panel 2000-2001 the loss is of 329 households, from 3529 to 3200 . The advantage of only using such households is that exactly the same individuals are observed in two subsequent years.

- $M$ is a set of dummies capturing the month of diary keeping. So, for instance in the panel 2000-2001, there is a dummy for households that kept the diary in January 2000 and in January 2001 and a different dummy for households that kept the diary in January 2000 and in February 2001. Potentially, there are 144 month dummies. However, in both panels, around $70 \%$ of the households kept the diary in the same month in both years.

- "Employees" are defined as employees in public or private enterprises, institutions, co-operatives, private entrepreneurs or societies (firms owned by several private entrepreneurs) with positive earnings from their main activity during the year and positive months in which earnings from the main activity have been realized. "Public employees" are defined as employees in public or private enterprises, institutions active in public administration and defence, compulsory social security, education, or health and social work. "Private employees" are all employees who are 
not public employees. The dataset contains the number of months in which earnings from the main activity have been realized during the year. If in a given year the number of months corresponds to twelve, the employee is considered to have been employed the whole year.

- Employee characteristics include three sets of "dummies", describing the labour market characteristics of employees in the households.

1. Sectoral: the number of employees in the household working in each of the 60 branches according to two-digit ISIC (e.g. manufacture of textiles);

2. Position: the number of employees in the household belonging to each of the 10 categories characterising the hierarchical position ${ }^{31}$ (e.g. skilled worker);

3. Type of employer: the number of employees in the household working for different types of employers ${ }^{32}$ (e.g. private entrepreneurs);

- Geographical dummies include a set of dummies for the 20 counties into which Hungary is divided and a set of dummies capturing whether the household place of residence is the capital, a large city, a town or a village. Note that by construction, in subsequent years the survey only includes households whose place of residence did not change.

- Income variables include household level income ${ }^{33}$, the sum of net personal incomes of household members ${ }^{34}$, plus other components $^{35}$. A

\footnotetext{
${ }^{31}$ top leader; leader, manager; employee with diploma; employee with secondary qualification; administrative employee; skilled worker; semi-skilled worker; unskilled worker; self-employed; family helper;

${ }^{32}$ In 1999, the following three categories are listed: 1. public or private enterprises, institutions; 2. cooperatives, firm owned by several private entrepreneurs; 3 . private entrepreneurs.

In 2000 and 2001, the following four categories are listed: 1. public or private enterprises, institutions; 2. cooperatives; 3 . private entrepreneurs; 4 . firm owned by several private entrepreneurs.

${ }^{33} \mathrm{e}$.g. family allowance, income from dividends, income from agricultural sales.

${ }^{34}$ e.g. income from main activity, self-employment, authorship. Paid social security contributions and personal income tax are subtracted from gross personal income to obtain net personal income.

${ }^{35} \mathrm{e} . \mathrm{g}$. income from sales of belonging. Outgoing household transfers, like maintenance for a child outside the household, are subtracted.
} 
distinction is made between two types of income, including home production or not. In a household budget survey, it is questionable whether we should consider income data as true income or income reported to fiscal authorities. The interview collecting data for yearly income is conducted around the time of filling the tax declaration form and the surveyors should get their data from it or from some other type of documentation whenever possible. For these reasons, we consider our income data as income reported to fiscal authorities. If income data actually corresponded to true income, then, after controlling for that, we should not find any effect of a shock to underreporting, as it would be fully accounted for by the income change.

- Food consumption is aggregated from very detailed consumption items. A distinction is made between food bought in the market and food produced at home. 


\section{Tables}

TABLE 1 - Labour Market Status - Whole Sample

2001

\begin{tabular}{|l|c|c|c|c|c|c|}
\hline & Employed & Retired & Child care & Unemployed & Other & Total \\
\hline Employed & $32.5 \%$ & $1.3 \%$ & $0.4 \%$ & $1.7 \%$ & $0.3 \%$ & $\mathbf{3 6 \%}$ \\
\hline Retired & $0.4 \%$ & $40.1 \%$ & $0.0 \%$ & $0.1 \%$ & $0.8 \%$ & $\mathbf{4 1} \%$ \\
\hline Child care & $0.8 \%$ & $0.0 \%$ & $2.8 \%$ & $0.2 \%$ & $0.2 \%$ & $\mathbf{4} \%$ \\
\hline Unemployed & $2.0 \%$ & $0.2 \%$ & $0.1 \%$ & $2.5 \%$ & $0.5 \%$ & $\mathbf{5} \%$ \\
\hline Other & $1.0 \%$ & $0.5 \%$ & $0.1 \%$ & $0.5 \%$ & $10.8 \%$ & $\mathbf{1 3} \%$ \\
\hline Total & $\mathbf{3 7} \%$ & $\mathbf{4 2} \%$ & $\mathbf{3} \%$ & $\mathbf{5} \%$ & $\mathbf{1 3} \%$ & $\mathbf{1 0 0} \%$ \\
\hline
\end{tabular}

NB: Only people present for both years (Total: 7064)
1999

\begin{tabular}{|l|c|c|c|c|c|c|}
\hline & Employed & Retired & Child care & Unemployed & Other & Total \\
\hline Employed & $31.9 \%$ & $0.6 \%$ & $0.6 \%$ & $2.2 \%$ & $1.4 \%$ & $\mathbf{3 7 \%}$ \\
\hline Retired & $0.9 \%$ & $40.1 \%$ & $0.0 \%$ & $0.2 \%$ & $0.7 \%$ & $\mathbf{4 2} \%$ \\
\hline Child care & $0.5 \%$ & $0.0 \%$ & $3.1 \%$ & $0.0 \%$ & $0.1 \%$ & $\mathbf{4} \%$ \\
\hline Unemployed & $1.8 \%$ & $0.0 \%$ & $0.3 \%$ & $2.4 \%$ & $1.3 \%$ & $\mathbf{6} \%$ \\
\hline Other & $0.2 \%$ & $0.3 \%$ & $0.2 \%$ & $0.4 \%$ & $10.8 \%$ & $\mathbf{1 2} \%$ \\
\hline Total & $\mathbf{3 5} \%$ & $\mathbf{4 1} \%$ & $\mathbf{4} \%$ & $\mathbf{5} \%$ & $\mathbf{1 4 \%}$ & $\mathbf{1 0 0} \%$ \\
\hline
\end{tabular}

NB: Only people present for both years (Total: 7207) 
TABLE 2a - Descriptive Statistics: "Potential Treatment"

\begin{tabular}{|c|c|c|c|c|c|c|c|c|}
\hline & \multirow{2}{*}{\multicolumn{3}{|c|}{\begin{tabular}{l|l} 
T & \\
PANEL 1999-2000
\end{tabular}}} & \multicolumn{2}{|l|}{150} & \multicolumn{3}{|c|}{200} \\
\hline & & & & & & & & \\
\hline Number of households & \multicolumn{2}{|c|}{197} & \multicolumn{3}{|c|}{412} & \multicolumn{3}{|c|}{651} \\
\hline Number of "treated" among HH members & \multicolumn{2}{|c|}{1.1} & \multirow{2}{*}{\multicolumn{3}{|c|}{$\begin{array}{c}0 \\
12\end{array}$}} & \multirow{2}{*}{\multicolumn{3}{|c|}{$\begin{array}{c}0 \\
12\end{array}$}} \\
\hline Number of "control" among $\mathrm{HH}$ members & 0.2 & 0.3 & & & & & & \\
\hline \multirow[t]{2}{*}{ (for $T$ the two figures refer to 150 and 200 ) } & mean & sd & mean & sd & t-stat & mean & sd & t-stat \\
\hline & \multicolumn{8}{|c|}{1999} \\
\hline $\mathrm{N}$ of $\mathrm{HH}$ members & 3.2 & 1.1 & 3.2 & 1.1 & -0.04 & 3.2 & 1.1 & -0.02 \\
\hline Area of the dwelling (m2) & 80 & 28 & 80 & 28 & -0.02 & 79 & 28 & 0.31 \\
\hline Expenditures on food (no home prod.; M) & 18564 & 8970 & 20455 & 8764 & -2.45 & 20960 & 9208 & -3.26 \\
\hline Total net income HH (no home prod); (A/12) & 74341 & 28615 & 80302 & 29919 & -2.37 & 83767 & 30582 & -3.99 \\
\hline Own production: total (M) & 7429 & 7478 & 7070 & 7799 & 0.55 & 6702 & 7591 & 1.19 \\
\hline Own production: food (M) & 7082 & 7086 & 6785 & 7472 & 0.48 & 6410 & 7231 & 1.16 \\
\hline $\mathrm{HH}$ level income from main activity & 69409 & 40815 & 77827 & 43039 & -2.34 & 83858 & 46057 & -4.22 \\
\hline HH level income from self-employment & 2608 & 12733 & 1226 & 8986 & 1.37 & 1448 & 9120 & 1.19 \\
\hline Total expenditures & 75013 & 29849 & 75995 & 27823 & -0.39 & 79148 & 29139 & -1.71 \\
\hline Total expenditures with durables & 78994 & 34114 & 79092 & 31653 & -0.03 & 82209 & 32719 & -1.17 \\
\hline Expenditures on food as $\%$ of: expenditures & $25 \%$ & & $27 \%$ & & & $26 \%$ & & \\
\hline net income & $25 \%$ & & $25 \%$ & & & $25 \%$ & & \\
\hline & & & & 20 & & & & \\
\hline $\mathrm{N}$ of $\mathrm{HH}$ members & 3.2 & 1.1 & 3.2 & 1.1 & -0.04 & 3.2 & 1.1 & -0.02 \\
\hline Area of the dwelling (m2) & 79 & 26 & 80 & 29 & -0.33 & 79 & 28 & 0.16 \\
\hline Expenditures on food (no home prod.; M) & 20181 & 9335 & 22796 & 10309 & -3.13 & 23413 & 10441 & -4.14 \\
\hline Total net income $\mathrm{HH}$ (no home prod); (A/12) & 82338 & 32431 & 90999 & 33160 & -3.06 & 95225 & 33690 & -4.84 \\
\hline Own production: total (M) & 7867 & 7938 & 7168 & 8619 & 0.99 & 6889 & 8275 & 1.50 \\
\hline Own production: food (M) & 7612 & 7693 & 6853 & 8126 & 1.12 & 6573 & 7787 & 1.66 \\
\hline $\mathrm{HH}$ level income from main activity & 73226 & 44117 & 85009 & 45836 & -3.04 & 93552 & 49283 & -5.51 \\
\hline $\mathrm{HH}$ level income from self-employment & 2493 & 12936 & 1471 & 9900 & 0.98 & 1736 & 10550 & 0.75 \\
\hline Total expenditures & 82402 & 30491 & 83198 & 33869 & -0.29 & 86292 & 33267 & -1.54 \\
\hline Total expenditures with durables & 86651 & 34605 & 86382 & 40609 & 0.08 & 89667 & 38940 & -1.04 \\
\hline Expenditures on food as $\%$ of: expenditures & $24 \%$ & & $27 \%$ & & & $27 \%$ & & \\
\hline net income & $25 \%$ & & $25 \%$ & & & $25 \%$ & & \\
\hline Increase in HH net income YY (HUF; \%): & 7997 & $11 \%$ & 10697 & $13 \%$ & & 11457 & $14 \%$ & \\
\hline Increase in $\mathrm{HH}$ food consumption $\mathrm{YY}$ (HUF; \%): & 1617 & $9 \%$ & 2341 & $11 \%$ & & 2453 & $12 \%$ & \\
\hline & & JEL 20 & $0-2001$ & & & & & \\
\hline Number of households & $\overline{19}$ & & & 369 & & & 587 & \\
\hline Number of "treated" among HH members & 1. & & & 0 & & & 0 & \\
\hline Number of "control" among $\mathrm{HH}$ members & 0.3 & 0.4 & & 1.2 & & & 1.2 & \\
\hline (for $T$ the two figures refer to 150 and 200 ) & mean & sd & mean & sd & t-stat & mean & sd & t-stat \\
\hline & & & & 20 & & & & \\
\hline $\mathrm{N}$ of $\mathrm{HH}$ members & 3.3 & 1.3 & 3.2 & 1.1 & 1.18 & 3.2 & 1.1 & 1.20 \\
\hline Area of the dwelling (m2) & 80 & 25 & 80 & 26 & 0.04 & 79 & 26 & 0.46 \\
\hline Expenditures on food (no home prod.; M) & 21032 & 9599 & 22218 & 9967 & -1.38 & 23167 & 10545 & -2.63 \\
\hline Total net income $\mathrm{HH}$ (no home prod); (A/12) & 80901 & 33731 & 87978 & 30028 & -2.46 & 92221 & 30673 & -4.15 \\
\hline Own production: total (M) & 7457 & 7622 & 7806 & 8478 & -0.50 & 7226 & 8184 & 0.36 \\
\hline Own production: food (M) & 7255 & 7497 & 7448 & 8022 & -0.28 & 6912 & 7775 & 0.55 \\
\hline $\mathrm{HH}$ level income from main activity & 71154 & 43404 & 81189 & 42358 & -2.63 & 90179 & 45696 & -5.23 \\
\hline $\mathrm{HH}$ level income from self-employment & 3599 & 17535 & 1724 & 11312 & 1.35 & 1877 & 11876 & 1.28 \\
\hline Total expenditures & 79313 & 30274 & 81606 & 30824 & -0.85 & 86029 & 33068 & -2.62 \\
\hline Total expenditures with durables & 82829 & 34330 & 85719 & 39758 & -0.90 & 90646 & 40600 & -2.63 \\
\hline Expenditures on food as $\%$ of: expenditures & $27 \%$ & & $27 \%$ & & & $27 \%$ & & \\
\hline net income & $26 \%$ & & $25 \%$ & & & $25 \%$ & & \\
\hline & & & & 20 & & & & \\
\hline $\mathrm{N}$ of $\mathrm{HH}$ members & 3.3 & 1.3 & 3.2 & 1.1 & 1.18 & 3.2 & 1.1 & 1.20 \\
\hline Area of the dwelling (m2) & 80 & 25 & 81 & 27 & -0.27 & 80 & 27 & 0.16 \\
\hline Expenditures on food (no home prod.; M) & 25229 & 11294 & 27102 & 11626 & -1.85 & 28354 & 12795 & -3.23 \\
\hline Total net income $\mathrm{HH}$ (no home prod); (A/12) & 101066 & 38845 & 103751 & 34469 & -0.81 & 107925 & 34941 & -2.19 \\
\hline Own production: total (M) & 8663 & 9547 & 7814 & 9725 & 1.00 & 7152 & 9132 & 1.93 \\
\hline Own production: food (M) & 8439 & 9389 & 7433 & 9183 & 1.22 & 6804 & 8660 & 2.15 \\
\hline $\mathrm{HH}$ level income from main activity & 93176 & 53270 & 97730 & 51349 & -0.98 & 105582 & 54156 & -2.81 \\
\hline $\mathrm{HH}$ level income from self-employment & 3765 & 17061 & 1933 & 12845 & 1.32 & 2478 & 15503 & 0.93 \\
\hline Total expenditures & 97268 & 36233 & 98179 & 37042 & -0.28 & 101653 & 38120 & -1.45 \\
\hline Total expenditures with durables & 100630 & 41548 & 103488 & 42620 & -0.77 & 106724 & 43558 & -1.75 \\
\hline Expenditures on food as $\%$ of: expenditures & $26 \%$ & & $28 \%$ & & & $28 \%$ & & \\
\hline net income & $25 \%$ & & $26 \%$ & & & $26 \%$ & & \\
\hline Increase in HH net income YY (HUF; \%): & 20165 & $25 \%$ & 15773 & $18 \%$ & & 15703 & $17 \%$ & \\
\hline Increase in $\mathrm{HH}$ food consumption YY (HUF; \%): & 4198 & $20 \%$ & 4884 & $22 \%$ & & 5186 & $22 \%$ & \\
\hline
\end{tabular}


TABLE 2b - Results: "Potential Treatment" - Panel 2000-2001

Dependent variable:

$\Delta$ Food Consumption (excluding own production); monthly

\begin{tabular}{|c|c|c|c|c|c|c|c|c|c|c|c|c|}
\hline Sample: & \multicolumn{6}{|c|}{ MW2000<Wage 2000<2* MW2001 } & \multicolumn{6}{|c|}{ MW2000<Wage $2000<1.5^{*}$ MW2001 } \\
\hline Treatment & $-1287^{\star \star}$ & $-1538^{\star \star}$ & $-1298^{*}$ & $-1084^{\star}$ & $-1328^{\star \star}$ & $-1158^{*}$ & -1029 & -1218 & -1063 & -785 & -963 & -838 \\
\hline Ireatment & (644) & (655) & (661) & (635) & (646) & (648) & (733) & (745) & (749) & (719) & (731) & (733) \\
\hline $\begin{array}{l}\Delta \mathrm{HH} \text { Income - no Home } \\
\text { Production }\end{array}$ & - & $\begin{array}{l}0.05^{\star \star \star} \\
(0.021)\end{array}$ & $\begin{array}{l}0.06^{\star \star *} \\
(0.021)\end{array}$ & - & - & - & - & $\begin{array}{l}0.04^{*} \\
(0.023)\end{array}$ & $\begin{array}{l}0.05^{\star *} \\
(0.023)\end{array}$ & - & - & - \\
\hline $\begin{array}{l}\text { HH Income - no Home } \\
\text { Production; } 2000\end{array}$ & - & - & $\begin{array}{l}0.03^{\star \star \star} \\
(0.011)\end{array}$ & - & - & - & - & - & $\begin{array}{l}0.03^{* *} \\
(0.013)\end{array}$ & - & - & - \\
\hline $\begin{array}{l}\Delta \text { Food own production; } \\
\text { monthly }\end{array}$ & - & - & - & $\begin{array}{c}-0.17^{\star \star \star} \\
(0.063)\end{array}$ & $\begin{array}{l}-0.21^{* \star *} \\
(0.066)\end{array}$ & $\begin{array}{c}-0.21^{* * *} \\
(0.065)\end{array}$ & - & - & - & $\begin{array}{l}-0.19^{\star \star \star} \\
(0.070)\end{array}$ & $\begin{array}{l}-0.22^{\star \star \star} \\
(0.073)\end{array}$ & $\begin{array}{c}-0.23^{\star * \star} \\
(0.071)\end{array}$ \\
\hline $\begin{array}{l}\Delta H H \text { Income - with } \\
\text { Home Production }\end{array}$ & - & - & - & - & $\begin{array}{l}0.05^{\star \star} \\
(0.020)\end{array}$ & $\begin{array}{l}0.05^{\star \star \star} \\
(0.020)\end{array}$ & - & - & - & - & $\begin{array}{l}0.04^{*} \\
(0.023)\end{array}$ & $\begin{array}{l}0.04^{*} \\
(0.022)\end{array}$ \\
\hline $\begin{array}{l}\mathrm{HH} \text { Income - with Home } \\
\text { Production; } 2000\end{array}$ & - & - & - & - & - & $\begin{array}{l}0.02^{* \star} \\
(0.010)\end{array}$ & - & - & - & - & - & $\begin{array}{c}0.02^{\star} \\
(0.012) \\
\end{array}$ \\
\hline R-Squared & 0.30 & 0.31 & 0.32 & 0.31 & 0.31 & 0.32 & 0.30 & 0.31 & 0.32 & 0.32 & 0.32 & 0.33 \\
\hline Additional Controls: & \multicolumn{12}{|c|}{ Month dummies. } \\
\hline Treatment & $\begin{array}{c}-1942^{\star \star} \\
(824)\end{array}$ & $\begin{array}{c}\mathbf{- 2 1 7 8}^{\star \star \star} \\
(838)\end{array}$ & $\begin{array}{c}-1710^{\star} \\
(876)\end{array}$ & $\begin{array}{c}-1804^{\star \star} \\
(823)\end{array}$ & $\begin{array}{c}\mathbf{- 2 0 2 3}^{\star \star} \\
(835)\end{array}$ & $\begin{array}{c}-1751^{\star \star} \\
(874)\end{array}$ & $\begin{array}{c}-1843^{\star \star} \\
(923)\end{array}$ & $\begin{array}{c}-1936^{* *} \\
(931)\end{array}$ & $\begin{array}{c}-1591 \\
(970)\end{array}$ & $\begin{array}{c}-1646^{\star} \\
(907)\end{array}$ & $\begin{array}{c}-1729^{*} \\
(914)\end{array}$ & $\begin{array}{c}-1544 \\
(956)\end{array}$ \\
\hline $\begin{array}{l}\Delta \mathrm{HH} \text { Income - no Home } \\
\text { Production }\end{array}$ & - & $\begin{array}{l}0.05^{\star *} \\
(0.022)\end{array}$ & $\begin{array}{l}0.06^{* * *} \\
(0.023)\end{array}$ & - & - & - & - & $\begin{array}{c}0.03 \\
(0.025)\end{array}$ & $\begin{array}{c}0.04 \\
(0.026)\end{array}$ & - & - & - \\
\hline $\begin{array}{l}\mathrm{HH} \text { Income - no Home } \\
\text { Production; } 2000\end{array}$ & - & - & $\begin{array}{l}0.04^{* *} \\
(0.014)\end{array}$ & - & - & - & - & - & $\begin{array}{c}0.03^{*} \\
(0.017)\end{array}$ & - & - & - \\
\hline $\begin{array}{l}\Delta \text { Food own production; } \\
\text { monthly }\end{array}$ & - & - & - & $\begin{array}{c}-0.18^{\star \star *} \\
(0.069)\end{array}$ & $\begin{array}{l}-0.22^{\star \star \star} \\
(0.072)\end{array}$ & $\begin{array}{c}-0.21^{\star \star *} \\
(0.070)\end{array}$ & - & - & - & $\begin{array}{l}-0.19^{* *} \\
(0.080)\end{array}$ & $\begin{array}{c}-0.21^{\star \star \star} \\
(0.082)\end{array}$ & $\begin{array}{l}-0.21^{* * *} \\
(0.080)\end{array}$ \\
\hline $\begin{array}{l}\Delta \mathrm{HH} \text { Income - with } \\
\text { Home Production }\end{array}$ & - & - & - & - & $\begin{array}{l}0.05^{\star \star} \\
(0.022)\end{array}$ & $\begin{array}{l}0.05^{\star *} \\
(0.022)\end{array}$ & - & - & - & - & $\begin{array}{c}0.03 \\
(0.025)\end{array}$ & $\begin{array}{c}0.03 \\
(0.025)\end{array}$ \\
\hline $\begin{array}{l}\text { HH Income - with Home } \\
\text { Production; } 2000\end{array}$ & - & - & - & - & - & $\begin{array}{c}0.02 \\
(0.013)\end{array}$ & - & - & - & - & - & $\begin{array}{c}0.02 \\
(0.015)\end{array}$ \\
\hline R-Squared & 0.38 & 0.39 & 0.40 & 0.39 & $\frac{0.40}{1 \text { th }}$ & $\begin{array}{c}0.40 \\
\end{array}$ & 0.41 & 0.42 & 0.42 & 0.42 & 0.43 & 0.43 \\
\hline Additional Controls: & \multicolumn{12}{|c|}{ Month dummies, Employee characteristics for 2000.} \\
\hline Treatment & $\begin{array}{c}-1717^{\star \star} \\
(838)\end{array}$ & $\begin{array}{c}-1951^{\star \star} \\
(853)\end{array}$ & $\begin{array}{c}-1575^{\star} \\
(882)\end{array}$ & $\begin{array}{c}-1626^{\star} \\
(835)\end{array}$ & $\begin{array}{c}-1840^{\star \star} \\
(848)\end{array}$ & $\begin{array}{c}-1597^{\star} \\
(875)\end{array}$ & $\begin{array}{c}-1608^{\star} \\
(952)\end{array}$ & $\begin{array}{c}-1690^{*} \\
(959)\end{array}$ & $\begin{array}{c}-1449 \\
(984)\end{array}$ & $\begin{array}{c}-1485 \\
(941)\end{array}$ & $\begin{array}{c}-1554 \\
(946)\end{array}$ & $\begin{array}{c}-1435 \\
(975)\end{array}$ \\
\hline $\begin{array}{l}\Delta \mathrm{HH} \text { Income - no Home } \\
\text { Production }\end{array}$ & - & $\begin{array}{l}0.05^{\star \star} \\
(0.023)\end{array}$ & $\begin{array}{l}0.06^{* *} \\
(0.024)\end{array}$ & - & - & - & - & $\begin{array}{c}0.02 \\
(0.027)\end{array}$ & $\begin{array}{c}0.03 \\
(0.027)\end{array}$ & - & - & - \\
\hline $\begin{array}{l}\mathrm{HH} \text { Income - no Home } \\
\text { Production; } 2000\end{array}$ & - & - & $\begin{array}{l}0.03^{* *} \\
(0.015)\end{array}$ & - & - & - & - & - & $\begin{array}{c}0.02 \\
(0.017)\end{array}$ & - & - & - \\
\hline $\begin{array}{l}\Delta \text { Food own production; } \\
\text { monthly }\end{array}$ & - & - & - & $\begin{array}{c}-0.19^{\star * *} \\
(0.070)\end{array}$ & $\begin{array}{l}-0.22^{* * *} \\
(0.073)\end{array}$ & $\begin{array}{c}-0.22^{* * *} \\
(0.072)\end{array}$ & - & & (2) & $\begin{array}{l}-0.18^{\star *} \\
(0.080)\end{array}$ & $\begin{array}{l}-0.20^{* *} \\
(0.082)\end{array}$ & $\begin{array}{l}-0.20^{\star \star} \\
(0.081)\end{array}$ \\
\hline $\begin{array}{l}\Delta \mathrm{HH} \text { Income - with } \\
\text { Home Production }\end{array}$ & - & - & - & - & $\begin{array}{l}0.05^{\star \star} \\
(0.023)\end{array}$ & $\begin{array}{l}0.05^{\star \star} \\
(0.023)\end{array}$ & - & . & . & - & $\begin{array}{c}0.02 \\
(0.026)\end{array}$ & $\begin{array}{c}0.02 \\
(0.027)\end{array}$ \\
\hline $\begin{array}{l}\text { HH Income - with Home } \\
\text { Production; } 2000\end{array}$ & - & - & - & - & - & $\begin{array}{c}0.02 \\
(0.014)\end{array}$ & - & 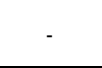 & - & - & - & $\begin{array}{c}0.01 \\
(0.016)\end{array}$ \\
\hline R-Squared & 0.41 & 0.42 & 0.42 & 0.42 & 0.43 & 0.43 & 0.45 & 0.45 & 0.46 & 0.46 & 0.46 & 0.46 \\
\hline Additional Controls: & \multicolumn{12}{|c|}{ Month dummies, Employee characteristics for 2000, Geographical dummies. } \\
\hline Number of $\mathrm{HH}$ & & & & 82 & & & & & & & & \\
\hline $\mathrm{HH}$ treated & & & & 95 & & & & & & & & \\
\hline
\end{tabular}

OLS estimation - Robust standard errors in brackets; ${ }^{*}$ significant at $10 \% ;{ }^{* *}$ significant at $5 \%$; ${ }^{* * *}$ significant at $1 \%$.

Treatment: Number of household members employed for the whole period earnings in the private sector a wage in 2000 between $100 \%$ of the minimum wage in 2000 and $100 \%$ of the minimum wage in 2001 ;

Sample:

Households with constant family structure and positive income below 200,000 HUF in both years, with at least one member employed for the whole period, earning in 2000 between $100 \%$ of the minimum wage in 2000 and $200 \%(150 \%)$ of the minimum wage in 2001; 
TABLE 2c - Results: "Potential Treatment" - Panel 1999-2000 - Placebo

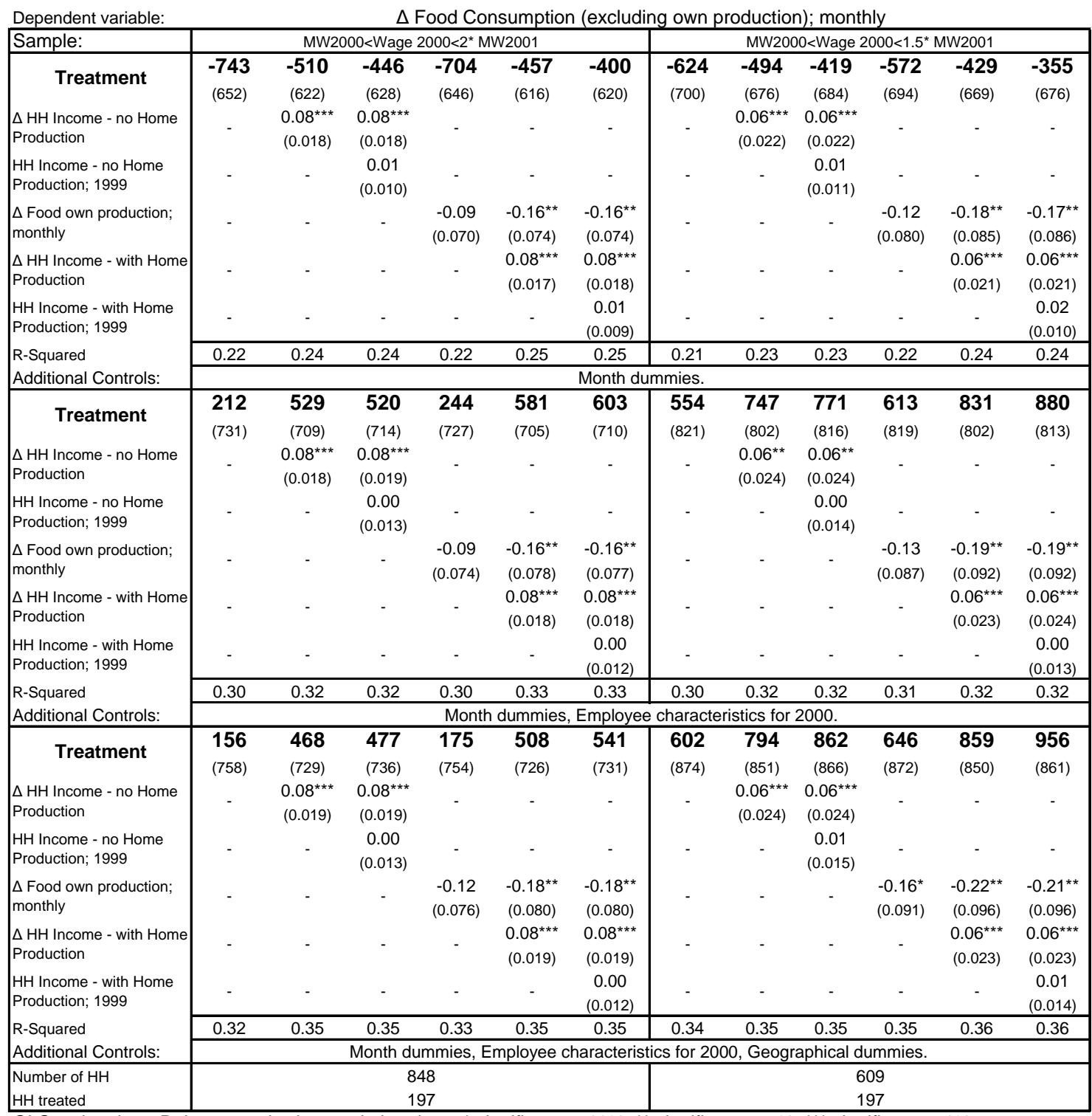

OLS estimation - Robust standard errors in brackets; ${ }^{*}$ significant at 10\%; ${ }^{* *}$ significant at $5 \%$; ${ }^{* \star *}$ significant at $1 \%$.

Treatment: $\quad$ Number of household members employed for the whole period earnings in the private sector a wage in 2000 between $100 \%$ of the minimum wage in 2000 and $100 \%$ of the minimum wage in 2001 ;

Households with constant family structure and positive income below 200,000 HUF in both years, with at least one member employed for the whole period, earning in 2000 between $100 \%$ of the minimum wage in 2000 and $200 \%$ $(150 \%)$ of the minimum wage in 2001 ; 
TABLE 3a - Descriptive Statistics: "Actual Treatment"

\begin{tabular}{|c|c|c|c|c|c|c|c|c|}
\hline \multirow{5}{*}{$\begin{array}{l}\text { Number of households } \\
\text { Number of "treated" among HH members } \\
\text { Number of "control" among HH members } \\
\text { (for } T \text { the two figures refers to } 150 \text { and 200) }\end{array}$} & \multicolumn{2}{|c|}{$\bar{T}$} & \multicolumn{3}{|c|}{150} & \multicolumn{3}{|c|}{200} \\
\hline & \multicolumn{2}{|c|}{149} & \multicolumn{3}{|c|}{422} & \multicolumn{3}{|c|}{659} \\
\hline & \multicolumn{2}{|c|}{1.1} & \multirow{2}{*}{\multicolumn{3}{|c|}{$\begin{array}{c}0 \\
12\end{array}$}} & \multirow{2}{*}{\multicolumn{3}{|c|}{$\begin{array}{c}0 \\
13\end{array}$}} \\
\hline & 0.3 & 0.4 & & & & & & \\
\hline & mean & sd & mean & sd & t-stat & mean & sd & t-stat \\
\hline & \multicolumn{8}{|c|}{2000} \\
\hline $\mathrm{N}$ of $\mathrm{HH}$ members & $\overline{3.2}$ & 1.2 & $\overline{3.3}$ & 1.2 & -0.77 & $\overline{3.2}$ & 1.2 & -0.04 \\
\hline Area of the dwelling (m2) & 80 & 26 & 78 & 25 & 0.83 & 79 & 26 & 0.74 \\
\hline Expenditures on food (no home prod.; M) & 20016 & 9493 & 22214 & 10291 & -2.38 & 22374 & 10490 & -2.68 \\
\hline Total net income HH (no home prod); (A/12) & 75383 & 32039 & 87727 & 31292 & -4.07 & 89588 & 31588 & -4.90 \\
\hline Own production: total (M) & 7473 & 7712 & 7488 & 8389 & -0.02 & 7562 & 8616 & -0.13 \\
\hline Own production: food (M) & 7260 & 7622 & 7163 & 7935 & 0.13 & 7253 & 8231 & 0.01 \\
\hline $\mathrm{HH}$ level income from main activity & 67010 & 41104 & 77370 & 48826 & -2.51 & 82687 & 49099 & -4.05 \\
\hline $\mathrm{HH}$ level income from self-employment & 1733 & 9311 & 2715 & 15924 & -0.90 & 2833 & 15306 & -1.14 \\
\hline Total expenditures & 78188 & 29696 & 81190 & 32810 & -1.03 & 83918 & 34515 & -2.06 \\
\hline Total expenditures with durables & 81031 & 31789 & 85169 & 41237 & -1.26 & 87965 & 40623 & -2.28 \\
\hline \multirow{3}{*}{$\begin{array}{r}\text { Expenditures on food as \% of: expenditures } \\
\text { net income }\end{array}$} & $26 \%$ & & $27 \%$ & & & $27 \%$ & & \\
\hline & $27 \%$ & & $25 \%$ & & & $25 \%$ & & \\
\hline & \multicolumn{8}{|c|}{2001} \\
\hline $\mathrm{N}$ of $\mathrm{HH}$ members & 3.2 & 1.2 & 3.3 & 1.2 & -0.77 & 3.2 & 1.2 & -0.04 \\
\hline Area of the dwelling (m2) & 80 & 26 & 79 & 26 & 0.44 & 79 & 27 & 0.31 \\
\hline Expenditures on food (no home prod.; M) & 23976 & 10657 & 27190 & 11811 & -3.07 & 27462 & 12185 & -3.51 \\
\hline Total net income HH (no home prod); (A/12) & 93069 & 36758 & 103022 & 33909 & -2.90 & 105246 & 34309 & -3.70 \\
\hline Own production: total (M) & 7836 & 8770 & 7419 & 9556 & 0.49 & 7407 & 9293 & 0.53 \\
\hline Own production: food (M) & 7561 & 8552 & 7083 & 9162 & 0.58 & 7103 & 8935 & 0.59 \\
\hline $\mathrm{HH}$ level income from main activity & 82209 & 44610 & 93702 & 50579 & -2.61 & 98557 & 51347 & -3.92 \\
\hline HH level income from self-employment & 3111 & 13998 & 2206 & 13997 & 0.68 & 2869 & 16552 & 0.18 \\
\hline Total expenditures & 92843 & 35777 & 97002 & 36648 & -1.21 & 98962 & 36732 & -1.88 \\
\hline Total expenditures with durables & 96970 & 42233 & 101538 & 41643 & -1.14 & 103359 & 40706 & -1.68 \\
\hline Expenditures on food as $\%$ of: expenditures & $26 \%$ & & $28 \%$ & & & $28 \%$ & & \\
\hline net income & $26 \%$ & & $26 \%$ & & & $26 \%$ & & \\
\hline \multicolumn{9}{|l|}{ Increase in $\mathrm{HH}$ total net income: } \\
\hline absolute (HUF) & 17685 & & 15295 & & & 15657 & & \\
\hline percentage & $23 \%$ & & $17 \%$ & & & $17 \%$ & & \\
\hline \multicolumn{9}{|l|}{ Increase in expenditures on food: } \\
\hline absolute (HUF) & 3960 & & 4976 & & & 5088 & & \\
\hline percentage & $20 \%$ & & $22 \%$ & & & $23 \%$ & & \\
\hline
\end{tabular}


TABLE 3b - Results: "Actual Treatment" - Dummy - Panel 2000-2001

\begin{tabular}{|c|c|c|c|c|c|c|c|c|c|c|c|c|}
\hline \multirow{2}{*}{$\begin{array}{l}\text { Dependent variable: } \\
\text { Sample: }\end{array}$} & \multicolumn{12}{|c|}{$\Delta$ Food Consumption (excluding own production); monthly } \\
\hline & \multicolumn{6}{|c|}{ MW2000<Wage $2000<2^{*}$ MW2001 } & \multicolumn{6}{|c|}{ MW2000<Wage $2000<1.5^{*}$ MW2001 } \\
\hline & $-1385^{\star \star}$ & $-1471^{\star \star}$ & $-1195^{\star}$ & $-1206^{\star}$ & $-1301^{\star \star}$ & $-1129^{\star}$ & $-1292^{\star}$ & $-1372^{\star}$ & -1172 & -1140 & $-1228^{\star}$ & -1076 \\
\hline Ireatiment & (651) & (643) & (653) & (643) & (635) & (637) & (739) & (731) & (733) & (731) & (723) & (717) \\
\hline $\begin{array}{l}\triangle \mathrm{HH} \text { Income - no Home } \\
\text { Production }\end{array}$ & - & $\begin{array}{l}0.05^{\star \star *} \\
(0.017)\end{array}$ & $\begin{array}{l}0.05^{\star \star *} \\
(0.017)\end{array}$ & - & - & - & - & $\begin{array}{l}0.05^{\star \star} \\
(0.022)\end{array}$ & $\begin{array}{l}0.05^{\star \star} \\
(0.022)\end{array}$ & - & - & - \\
\hline $\begin{array}{l}\text { HH Income - no Home } \\
\text { Production; } 2000\end{array}$ & - & - & $\begin{array}{l}0.03^{\star *} \\
(0.011)\end{array}$ & - & - & - & - & - & $\begin{array}{l}0.03^{*} \\
(0.013)\end{array}$ & - & - & - \\
\hline $\begin{array}{l}\Delta \text { Food own production; } \\
\text { monthly }\end{array}$ & - & - & - & $\begin{array}{c}-0.15^{\star * *} \\
(0.053)\end{array}$ & $\begin{array}{c}-0.19^{\star * *} \\
(0.055)\end{array}$ & $\begin{array}{c}-0.19^{* * *} \\
(0.054)\end{array}$ & - & - & - & $\begin{array}{l}-0.15^{*} \\
(0.075)\end{array}$ & $\begin{array}{l}-0.18^{\star *} \\
(0.076)\end{array}$ & $\begin{array}{l}-0.19^{* *} \\
(0.074)\end{array}$ \\
\hline $\begin{array}{l}\Delta \mathrm{HH} \text { Income - with Home } \\
\text { Production }\end{array}$ & - & - & - & - & $\begin{array}{l}0.04^{\star *} \\
(0.017)\end{array}$ & $\begin{array}{c}0.05^{\star \star \star} \\
(0.017)\end{array}$ & - & - & - & & $\begin{array}{l}0.04^{\star *} \\
(0.021)\end{array}$ & $\begin{array}{l}0.05^{\star *} \\
(0.021)\end{array}$ \\
\hline $\begin{array}{l}\text { HH Income - with Home } \\
\text { Production; } 2000\end{array}$ & - & - & - & - & - & $\begin{array}{l}0.02^{*} \\
(0.010)\end{array}$ & - & - & - & & - & $\begin{array}{c}0.02 \\
(0.012)\end{array}$ \\
\hline R-Squared & 0.31 & 0.32 & 0.32 & 0.32 & 0.33 & 0.33 & 0.34 & 0.35 & 0.36 & 0.35 & 0.36 & 0.36 \\
\hline Additional Controls: & \multicolumn{12}{|c|}{ Month dummies. } \\
\hline Treatment & $\begin{array}{c}-1766^{\star \star} \\
(744)\end{array}$ & $\begin{array}{c}-1745^{\star \star} \\
(744)\end{array}$ & $\begin{array}{c}-1401^{*} \\
(753)\end{array}$ & $\begin{array}{c}-1646^{\star \star} \\
(732)\end{array}$ & $\begin{array}{c}-1637^{\star \star} \\
(731)\end{array}$ & $\begin{array}{c}-1478^{\star \star} \\
(735)\end{array}$ & $\begin{array}{c}-1794^{\star \star} \\
(865)\end{array}$ & $\begin{array}{c}-1761^{\star \star} \\
(859)\end{array}$ & $\begin{array}{r}1518^{\star} \\
(855)\end{array}$ & $\begin{array}{c}-1684^{\star \star} \\
(856)\end{array}$ & $\begin{array}{c}-1665^{\star} \\
(851)\end{array}$ & $\begin{array}{r}-1500^{*} \\
(842)\end{array}$ \\
\hline $\begin{array}{l}\Delta \mathrm{HH} \text { Income - no Home } \\
\text { Production }\end{array}$ & - & $\begin{array}{l}0.04^{* *} \\
(0.019)\end{array}$ & $\begin{array}{l}0.06^{* \star *} \\
(0.020)\end{array}$ & 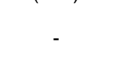 & - & - & (Dov) & $\begin{array}{l}0.04^{*} \\
(0.024)\end{array}$ & $\begin{array}{l}0.05^{\star *} \\
(0.026)\end{array}$ & (100) & - & 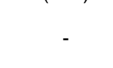 \\
\hline $\begin{array}{l}\text { HH Income - no Home } \\
\text { Production; } 2000\end{array}$ & - & - & $\begin{array}{l}0.03^{\star *} \\
(0.014)\end{array}$ & - & - & - & - & - & $\begin{array}{l}0.03^{*} \\
(0.017)\end{array}$ & - & - & - \\
\hline $\begin{array}{l}\Delta \text { Food own production; } \\
\text { monthly }\end{array}$ & - & - & - & $\begin{array}{c}-0.17^{* * *} \\
(0.056)\end{array}$ & $\begin{array}{c}-0.20^{* * *} \\
(0.058)\end{array}$ & $\begin{array}{c}-0.20^{* * *} \\
(0.057)\end{array}$ & - & - & - & $\begin{array}{l}-0.17^{* *} \\
(0.078)\end{array}$ & $\begin{array}{l}-0.21^{* *} \\
(0.080)\end{array}$ & $\begin{array}{l}-0.21^{* * *} \\
(0.078)\end{array}$ \\
\hline $\begin{array}{l}\Delta \mathrm{HH} \text { Income - with Home } \\
\text { Production }\end{array}$ & - & - & - & - & $\begin{array}{l}0.04^{* *} \\
(0.018)\end{array}$ & $\begin{array}{l}0.05^{\star \star} \\
(0.019)\end{array}$ & - & - & - & - & $\begin{array}{l}0.04^{*} \\
(0.023)\end{array}$ & $\begin{array}{l}0.05^{*} \\
(0.025)\end{array}$ \\
\hline $\begin{array}{l}\text { HH Income - with Home } \\
\text { Production; } 2000\end{array}$ & - & - & - & - & - & $\begin{array}{c}0.01 \\
(0.012)\end{array}$ & - & - & - & - & - & $\begin{array}{c}0.02 \\
(0.015)\end{array}$ \\
\hline R-Squared & 0.39 & 0.39 & 0.40 & 0.39 & 0.40 & 0.40 & 0.42 & 0.43 & 0.43 & 0.43 & 0.44 & 0.44 \\
\hline Additional Controls: & \multicolumn{12}{|c|}{ Month dummies, Employee characteristics for 2001.} \\
\hline Treatment & $\begin{array}{c}-1595^{\star \star} \\
(773)\end{array}$ & $\begin{array}{c}-1573^{\star \star} \\
(772)\end{array}$ & $\begin{array}{c}-1309^{\star} \\
(787)\end{array}$ & $\begin{array}{c}-1489^{\star \star} \\
(755)\end{array}$ & $\begin{array}{c}-1478^{\star} \\
(754)\end{array}$ & $\begin{array}{c}-1355^{\star} \\
(766)\end{array}$ & $\begin{array}{c}-1671^{*} \\
(893)\end{array}$ & $\begin{array}{c}-1624^{\star} \\
(887)\end{array}$ & $\begin{array}{c}-1441 \\
(890)\end{array}$ & $\begin{array}{c}-1585^{\star} \\
(879)\end{array}$ & $\begin{array}{c}-1552^{\star} \\
(873)\end{array}$ & $\begin{array}{c}-1433 \\
(872)\end{array}$ \\
\hline $\begin{array}{l}\Delta \mathrm{HH} \text { Income - no Home } \\
\text { Production }\end{array}$ & - & $\begin{array}{l}0.05^{\star *} \\
(0.019)\end{array}$ & $\begin{array}{l}0.06^{* * *} \\
(0.020)\end{array}$ & - & - & - & - & $\begin{array}{l}0.05^{\star *} \\
(0.024)\end{array}$ & $\begin{array}{l}0.06^{* *} \\
(0.026)\end{array}$ & - & - & - \\
\hline $\begin{array}{l}\text { HH Income - no Home } \\
\text { Production; } 2000\end{array}$ & - & - & $\begin{array}{l}0.03^{\star} \\
(0.015)\end{array}$ & - & - & - & - & - & $\begin{array}{c}0.03 \\
(0.018)\end{array}$ & - & - & - \\
\hline $\begin{array}{l}\Delta \text { Food own production; } \\
\text { monthly }\end{array}$ & - & - & - & $\begin{array}{c}-0.17^{\star \star *} \\
(0.059)\end{array}$ & $\begin{array}{c}-0.21^{* * *} \\
(0.061)\end{array}$ & $\begin{array}{c}-0.20^{\star \star \star} \\
(0.060)\end{array}$ & . & - & - & $\begin{array}{l}-0.19^{\star *} \\
(0.080)\end{array}$ & $\begin{array}{c}-0.23^{\star \star \star} \\
(0.081)\end{array}$ & $\begin{array}{c}-0.24^{\star \star \star} \\
(0.080)\end{array}$ \\
\hline $\begin{array}{l}\Delta \mathrm{HH} \text { Income - with Home } \\
\text { Production }\end{array}$ & - & - & - & - & $\begin{array}{l}0.04^{* *} \\
(0.019)\end{array}$ & $\begin{array}{l}0.05^{\star *} \\
(0.020)\end{array}$ & - & - & - & - & $\begin{array}{l}0.05^{* *} \\
(0.023)\end{array}$ & $\begin{array}{l}0.06^{\star *} \\
(0.025)\end{array}$ \\
\hline $\begin{array}{l}\text { HH Income - with Home } \\
\text { Production; } 2000\end{array}$ & - & - & - & - & - & $\begin{array}{c}0.01 \\
(0.013)\end{array}$ & - & - & - & - & - & $\begin{array}{c}0.02 \\
(0.017)\end{array}$ \\
\hline R-Squared & 0.41 & 0.42 & 0.42 & 0.42 & 0.43 & 0.43 & 0.45 & 0.45 & 0.46 & 0.46 & 0.46 & 0.47 \\
\hline Additional Controls: & \multicolumn{12}{|c|}{ Month dummies, Employee characteristics for 2001, Geographical dummies. } \\
\hline Number of $\mathrm{HH}$ & \multirow{2}{*}{\multicolumn{6}{|c|}{149}} & \multirow{2}{*}{\multicolumn{6}{|c|}{$\begin{array}{ll}571 \\
149\end{array}$}} \\
\hline $\mathrm{HH}$ treated & & & & & & & & & & & & \\
\hline \multicolumn{13}{|c|}{ OLS estimation - Robust standard errors in brackets; ${ }^{*}$ significant at $10 \% ;{ }^{* *}$ significant at $5 \% ;{ }^{* * *}$ significant at $1 \%$. } \\
\hline Treatment: & \multicolumn{12}{|c|}{$\begin{array}{l}\text { Number of household members employed in the private sector for the whole } 2001 \text { earning in } 2000 \text { between } 90 \% \text { of the minimum } \\
\text { wage in } 2000 \text { and } 110 \% \text { of the minimum wage in 2001, and in } 2001 \text { around the minimum wage in } 2001(90 \%-110 \%) \text {; }\end{array}$} \\
\hline Sample: & \multicolumn{12}{|c|}{$\begin{array}{l}\text { Households with constant family structure and positive income below } 200,000 \text { HUF in both years, with at least one employee for } \\
\text { the whole } 2001 \text { earning in } 2001 \text { between } 90 \% \text { and } 200 \%(150 \%) \text { of the minimum wage in } 2001 \text {; }\end{array}$} \\
\hline
\end{tabular}


TABLE 3c - Results: "Actual Treatment" - Continuous - Panel 2000-2001

\begin{tabular}{|c|c|c|c|c|c|c|c|c|c|c|c|c|}
\hline \multirow{2}{*}{$\begin{array}{l}\text { Dependent variable: } \\
\text { Sample: }\end{array}$} & \multicolumn{12}{|c|}{$\Delta$ Food Consumption (excluding own production); monthly } \\
\hline & \multicolumn{6}{|c|}{ MW2000<Wage $2000<2^{*}$ MW2001 } & \multicolumn{6}{|c|}{ MW2000<Wage $2000<1.5^{\star}$ MW2001 } \\
\hline & -0.09 & $-0.11^{*}$ & -0.09 & -0.08 & -0.09 & -0.08 & -0.08 & -0.10 & -0.08 & -0.07 & -0.09 & -0.08 \\
\hline reament & $(0.065)$ & $(0.063)$ & $(0.064)$ & $(0.064)$ & $(0.062)$ & $(0.062)$ & $(0.072)$ & $(0.070)$ & $(0.071)$ & $(0.070)$ & $(0.069)$ & (0.068) \\
\hline $\begin{array}{l}\Delta \mathrm{HH} \text { Income - no Home } \\
\text { Production }\end{array}$ & - & $\begin{array}{l}0.05^{* * *} \\
(0.017)\end{array}$ & $\begin{array}{l}0.05^{* * *} \\
(0.018)\end{array}$ & - & - & - & - & $\begin{array}{l}0.05^{\star *} \\
(0.022)\end{array}$ & $\begin{array}{l}0.05^{* *} \\
(0.022)\end{array}$ & - & - & - \\
\hline $\begin{array}{l}\text { HH Income - no Home } \\
\text { Production; } 2000\end{array}$ & - & - & $\begin{array}{l}0.03^{\star *} \\
(0.011)\end{array}$ & - & - & - & - & - & $\begin{array}{l}0.03^{\star *} \\
(0.013)\end{array}$ & - & - & - \\
\hline $\begin{array}{l}\Delta \text { Food own production; } \\
\text { monthly }\end{array}$ & - & - & - & $\begin{array}{l}-0.15^{\star \star *} \\
(0.053)\end{array}$ & $\begin{array}{l}-0.19^{* * *} \\
(0.055)\end{array}$ & $\begin{array}{l}-0.19^{* * *} \\
(0.054)\end{array}$ & - & - & - & $\begin{array}{l}-0.15^{\star \star} \\
(0.075)\end{array}$ & $\begin{array}{l}-0.19^{* *} \\
(0.076)\end{array}$ & $\begin{array}{l}-0.19^{\star *} \\
(0.074)\end{array}$ \\
\hline $\begin{array}{l}\Delta \mathrm{HH} \text { Income - with Home } \\
\text { Production }\end{array}$ & - & - & - & - & $\begin{array}{l}0.04^{* *} \\
(0.017)\end{array}$ & $\begin{array}{c}0.05^{* * *} \\
(0.017)\end{array}$ & - & - & - & - & $\begin{array}{l}0.04^{\star *} \\
(0.022)\end{array}$ & $\begin{array}{l}0.05^{\star *} \\
(0.022)\end{array}$ \\
\hline $\begin{array}{l}\text { HH Income - with Home } \\
\text { Production; } 2000\end{array}$ & - & - & - & - & - & $\begin{array}{c}0.02^{*} \\
(0.010) \\
\end{array}$ & - & - & - & - & - & $\begin{array}{l}0.02^{*} \\
(0.012)\end{array}$ \\
\hline R-Squared & 0.31 & 0.32 & 0.32 & 0.32 & 0.32 & 0.33 & 0.34 & 0.35 & 0.35 & 0.35 & 0.36 & 0.36 \\
\hline Additional Controls: & \multicolumn{12}{|c|}{ Month dummies. } \\
\hline Treatment & $-0.14^{\star}$ & $-0.14^{\star}$ & -0.11 & $-0.13^{\star}$ & $-0.13^{\star}$ & $-0.12^{*}$ & $-0.15^{\star}$ & $-0.16^{\star}$ & $-0.14^{\star}$ & $-0.14^{\star}$ & $-0.15^{\star}$ & $-0.14^{\star}$ \\
\hline Treatmeti & $(0.075)$ & $(0.074)$ & $(0.075)$ & $(0.073)$ & $(0.072)$ & $(0.073)$ & $(0.083)$ & $(0.082)$ & $(0.082)$ & $(0.081)$ & $(0.080)$ & $(0.080)$ \\
\hline $\begin{array}{l}\Delta \mathrm{HH} \text { Income - no Home } \\
\text { Production }\end{array}$ & - & $\begin{array}{l}0.04^{\star *} \\
(0.019)\end{array}$ & $\begin{array}{l}0.06^{\star * \star} \\
(0.020)\end{array}$ & - & - & - & - & $\begin{array}{l}0.04^{*} \\
(0.024)\end{array}$ & $\begin{array}{l}0.06^{* *} \\
(0.026)\end{array}$ & - & - & - \\
\hline $\begin{array}{l}\text { HH Income - no Home } \\
\text { Production; } 2000\end{array}$ & - & - & $\begin{array}{l}0.03^{\star *} \\
(0.014)\end{array}$ & - & - & - & - & - & $\begin{array}{l}0.03^{*} \\
(0.017)\end{array}$ & - & - & - \\
\hline $\begin{array}{l}\Delta \text { Food own production; } \\
\text { monthly }\end{array}$ & - & - & ( & $\begin{array}{l}-0.17^{\star * *} \\
(0.056)\end{array}$ & $\begin{array}{l}-0.20^{* * *} \\
(0.058)\end{array}$ & $\begin{array}{c}-0.20^{\star * *} \\
(0.057)\end{array}$ & - & - & - & $\begin{array}{l}-0.18^{\star *} \\
(0.078)\end{array}$ & $\begin{array}{l}-0.21^{\star * *} \\
(0.080)\end{array}$ & $\begin{array}{r}-0.21^{* * *} \\
(0.079)\end{array}$ \\
\hline $\begin{array}{l}\Delta \mathrm{HH} \text { Income - with Home } \\
\text { Production }\end{array}$ & - & - & - & - & $\begin{array}{l}0.04^{\star *} \\
(0.018)\end{array}$ & $\begin{array}{l}0.05^{\star *} \\
(0.019)\end{array}$ & - & - & - & - & $\begin{array}{l}0.04^{\star} \\
(0.023)\end{array}$ & $\begin{array}{l}0.05^{\star} \\
(0.025)\end{array}$ \\
\hline $\begin{array}{l}\text { HH Income - with Home } \\
\text { Production; } 2000\end{array}$ & - & - & - & - & - & $\begin{array}{c}0.01 \\
(0.012) \\
\end{array}$ & - & - & - & - & - & $\begin{array}{c}0.02 \\
(0.015) \\
\end{array}$ \\
\hline R-Squared & 0.38 & 0.39 & 0.40 & 0.39 & 0.40 & 0.40 & 0.42 & 0.43 & 0.43 & 0.43 & 0.44 & 0.44 \\
\hline Additional Controls: & \multicolumn{12}{|c|}{ Month dummies, Employee characteristics for 2001.} \\
\hline Treatment & $-0.14^{\star}$ & $-0.15^{\star}$ & -0.13 & $-0.14^{\star}$ & $-0.14^{\star}$ & $-0.13^{\star}$ & $-0.14^{\star}$ & $-0.15^{\star}$ & -0.14 & -0.14 & $-0.14^{*}$ & -0.14 \\
\hline Tedimeit & $(0.078)$ & $(0.077)$ & $(0.078)$ & $(0.075)$ & $(0.074)$ & $(0.075)$ & $(0.087)$ & $(0.086)$ & $(0.086)$ & $(0.085)$ & $(0.084)$ & $(0.084)$ \\
\hline $\begin{array}{l}\Delta \mathrm{HH} \text { Income - no Home } \\
\text { Production }\end{array}$ & - & $\begin{array}{l}0.05^{\star *} \\
(0.019)\end{array}$ & $\begin{array}{l}0.06^{\star * *} \\
(0.020)\end{array}$ & - & - & - & - & $\begin{array}{l}0.05^{\star \star} \\
(0.025)\end{array}$ & $\begin{array}{l}0.07^{\star *} \\
(0.026)\end{array}$ & - & - & - \\
\hline $\begin{array}{l}\text { HH Income - no Home } \\
\text { Production; } 2000\end{array}$ & - & - & $\begin{array}{l}0.03^{*} \\
(0.015)\end{array}$ & - & - & - & - & - & $\begin{array}{c}0.03 \\
(0.019)\end{array}$ & - & - & - \\
\hline $\begin{array}{l}\Delta \text { Food own production; } \\
\text { monthly }\end{array}$ & - & - & - & $\begin{array}{c}-0.17^{* * *} \\
(0.059)\end{array}$ & $\begin{array}{c}-0.21^{* \star *} \\
(0.061)\end{array}$ & $\begin{array}{c}-0.21^{\star * *} \\
(0.061)\end{array}$ & - & - & - & $\begin{array}{l}-0.20^{\star *} \\
(0.080)\end{array}$ & $\begin{array}{c}-0.24^{* * *} \\
(0.082)\end{array}$ & $\begin{array}{c}-0.24^{\star * *} \\
(0.081)\end{array}$ \\
\hline $\begin{array}{l}\Delta \mathrm{HH} \text { Income - with Home } \\
\text { Production }\end{array}$ & - & - & - & - & $\begin{array}{l}0.04^{\star *} \\
(0.019)\end{array}$ & $\begin{array}{l}0.05^{\star *} \\
(0.020)\end{array}$ & - & - & - & - & $\begin{array}{l}0.05^{\star *} \\
(0.023)\end{array}$ & $\begin{array}{l}0.06^{* *} \\
(0.025)\end{array}$ \\
\hline $\begin{array}{l}\text { HH Income - with Home } \\
\text { Production; } 2000\end{array}$ & - & - & - & - & - & $\begin{array}{c}0.01 \\
(0.013) \\
\end{array}$ & - & - & - & - & - & $\begin{array}{c}0.02 \\
(0.017) \\
\end{array}$ \\
\hline R-Squared & 0.41 & 0.42 & 0.42 & 0.42 & 0.43 & 0.43 & 0.45 & 0.45 & 0.46 & 0.46 & 0.46 & 0.47 \\
\hline Additional Controls: & \multicolumn{12}{|c|}{ Month dummies, Employee characteristics for 2001 , Geographical dummies. } \\
\hline $\begin{array}{l}\text { Number of } \mathrm{HH} \\
\mathrm{HH} \text { treated }\end{array}$ & \multicolumn{6}{|c|}{$\begin{array}{l}808 \\
114 \\
\end{array}$} & \multicolumn{6}{|c|}{$\begin{array}{l}571 \\
114 \\
\end{array}$} \\
\hline \multirow{2}{*}{\multicolumn{13}{|c|}{$\begin{array}{l}\text { OLS estimation - Robust standard errors in brackets; }{ }^{*} \text { significant at } 10 \% ;{ }^{* *} \text { significant at } 5 \% ;{ }^{* * *} \text { significant at } 1 \% . \\
\text { Sum within household of the difference between the minimum wage in } 2001 \text { and the wage in } 2000 \text { for all household } \\
\text { Treatment: } \\
\text { members employed in the private sector for the whole } 2001 \text { earning in } 2000 \text { between } 90 \% \text { of the minimum wage in } \\
2000 \text { and } 100 \% \text { of the minimum wage in } 2001 \text {, and in } 2001 \text { around the minimum wage in } 2001(90 \%-110 \%) ;\end{array}$}} \\
\hline & & & & & & & & & & & & \\
\hline Sample: & \multicolumn{12}{|c|}{$\begin{array}{l}\text { Households with constant family structure and positive income below } 200,000 \text { HUF in both years, with at least one } \\
\text { employee for the whole } 2001 \text { earning in } 2001 \text { between } 90 \% \text { and } 200 \%(150 \%) \text { of the minimum wage in } 2001 \text {; }\end{array}$} \\
\hline
\end{tabular}


TABLE 4 - Underground Economy and Minimum Wage Spike

Dependent variable: Spike at minimum wage level (2002)

\begin{tabular}{|c|c|}
\hline Informal Economy as \% official GDP (2001-2) & $0.279^{\star \star}$ \\
Minimum Wage / Average Wage (2002) & $(0.113)$ \\
& 0.179 \\
Constant & $(0.179)$ \\
& -8.337 \\
& $(8.381)$ \\
\hline R-Squared: & 0.30 \\
Number of observations: & 17 \\
\hline
\end{tabular}

OLS estimation - Standard errors in brackets;

${ }^{*}$ significant at $10 \%$; ${ }^{* *}$ significant at $5 \%$; ${ }^{* \star *}$ significant at $1 \%$. 


\section{Figures}

Figure 1: Declared Income

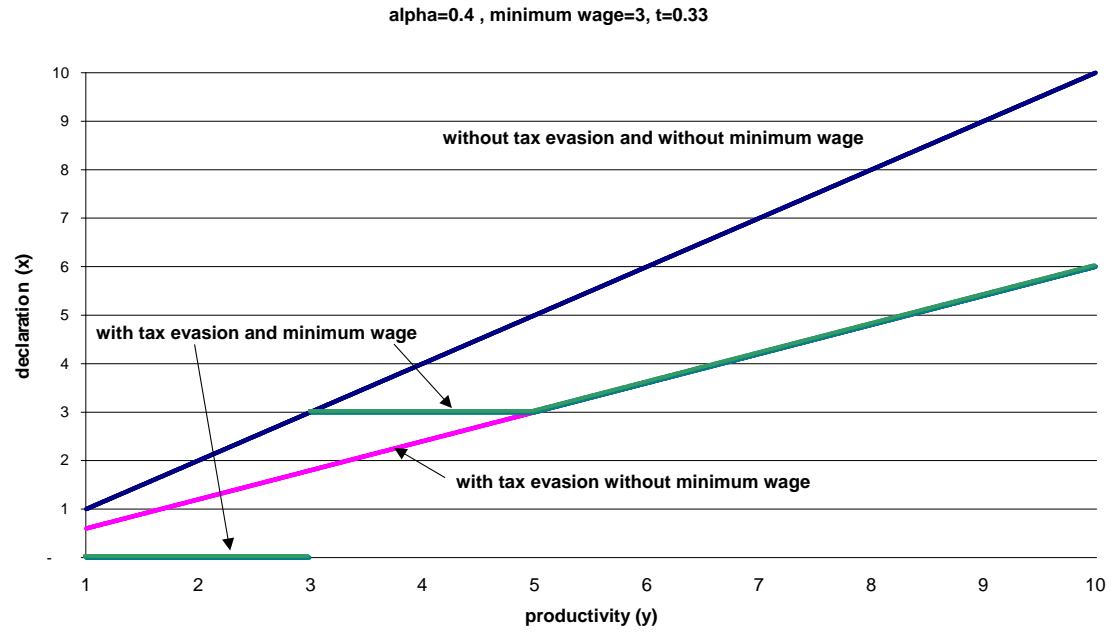


Figure 2: Effective Tax Rate

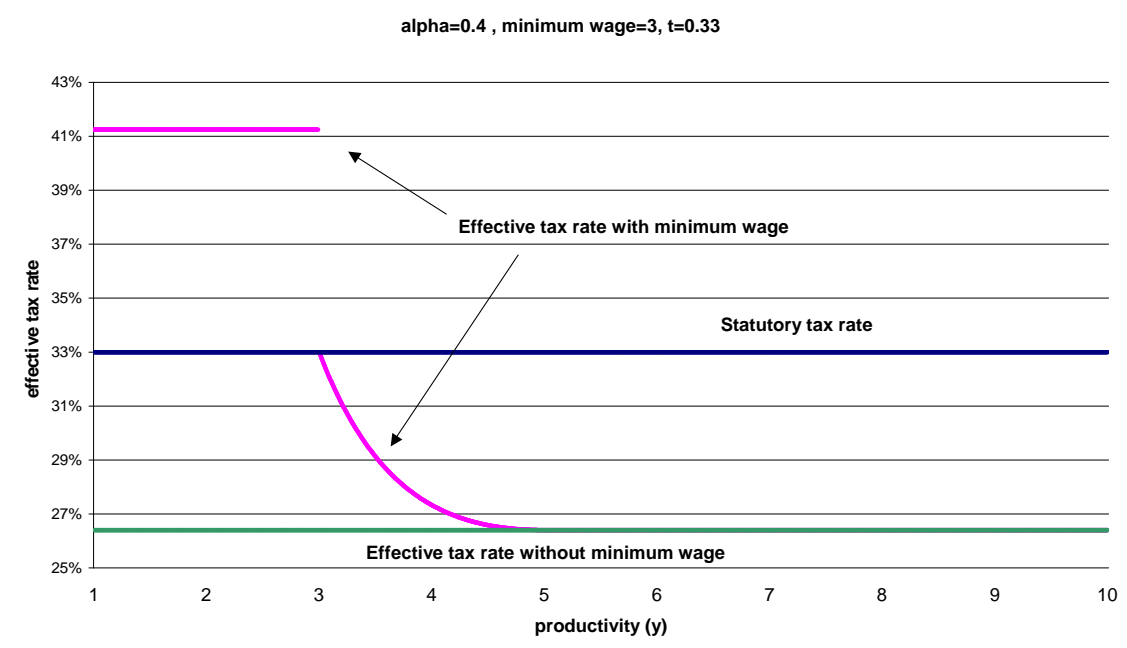

Effective Tax Rate $=$ Total Payments to Fiscal Authorities $/$ Productivity

Figure 3: Wage Dynamics in Hungary 1992-2005

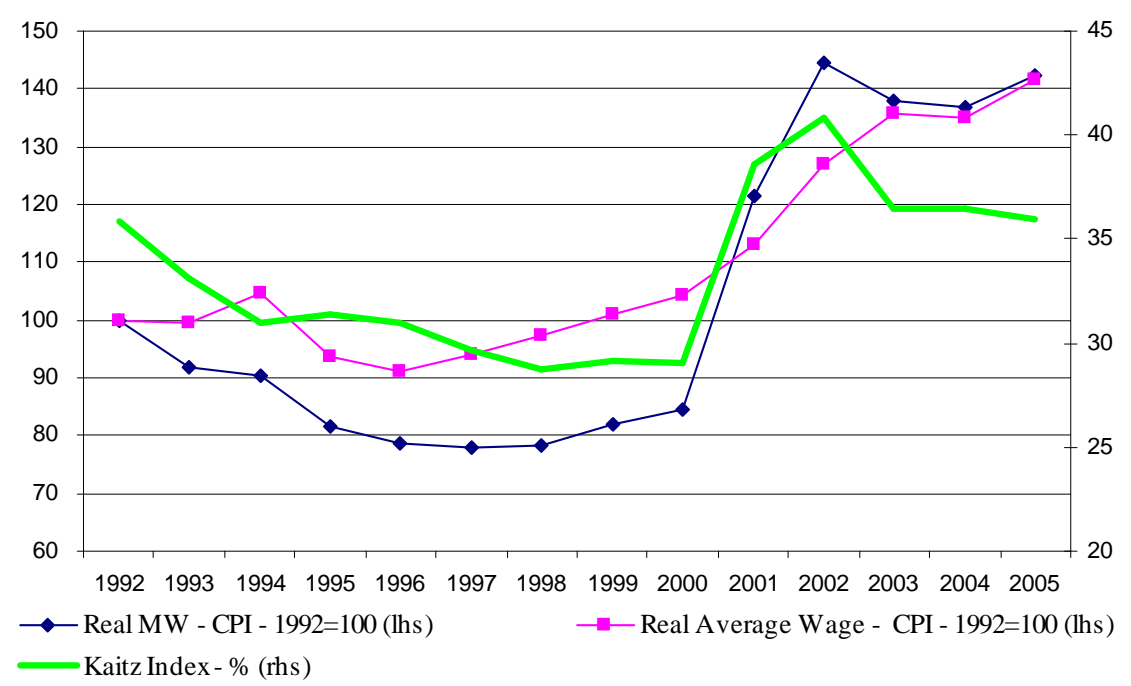


Figure 4: Earnings from main activity

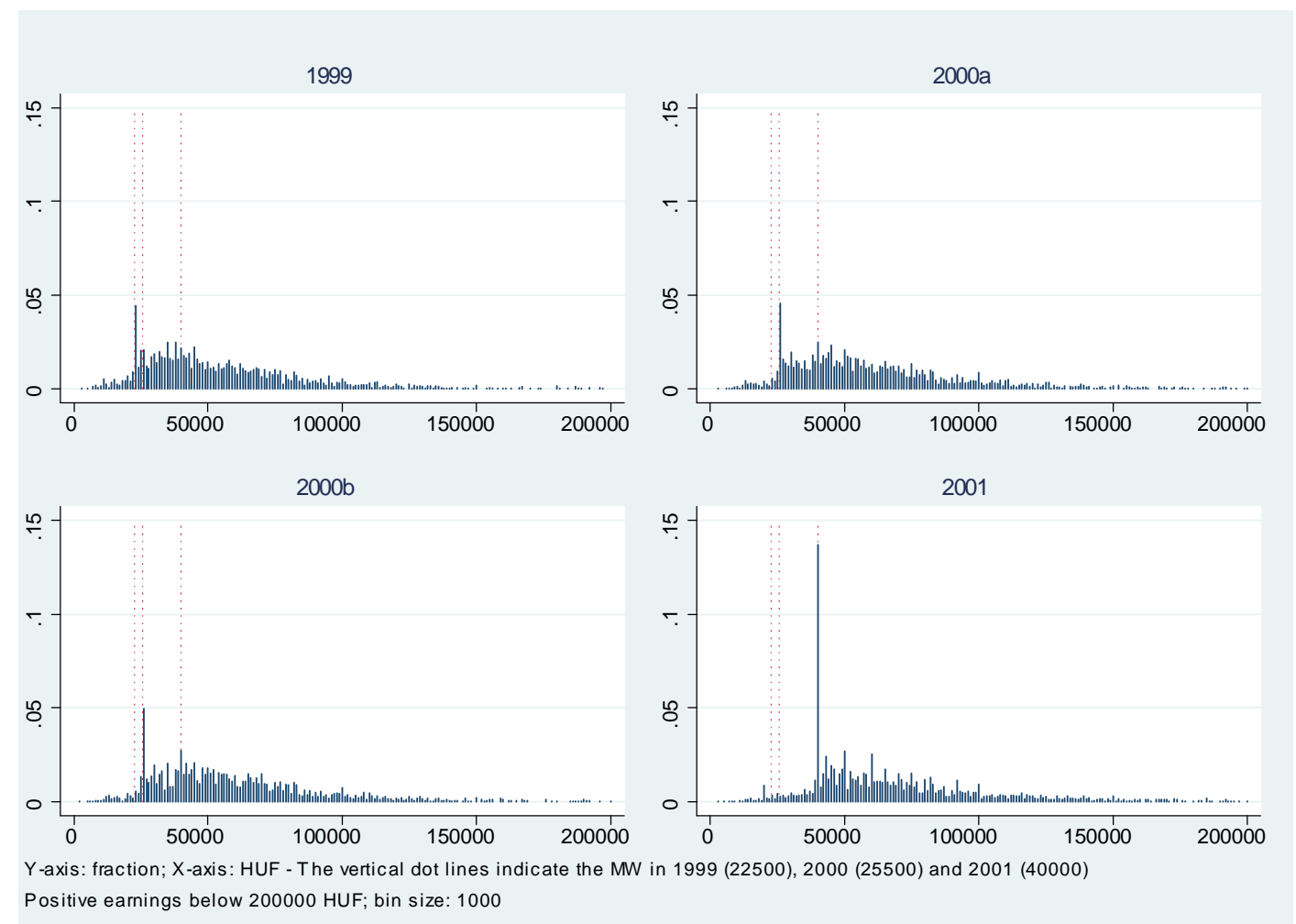




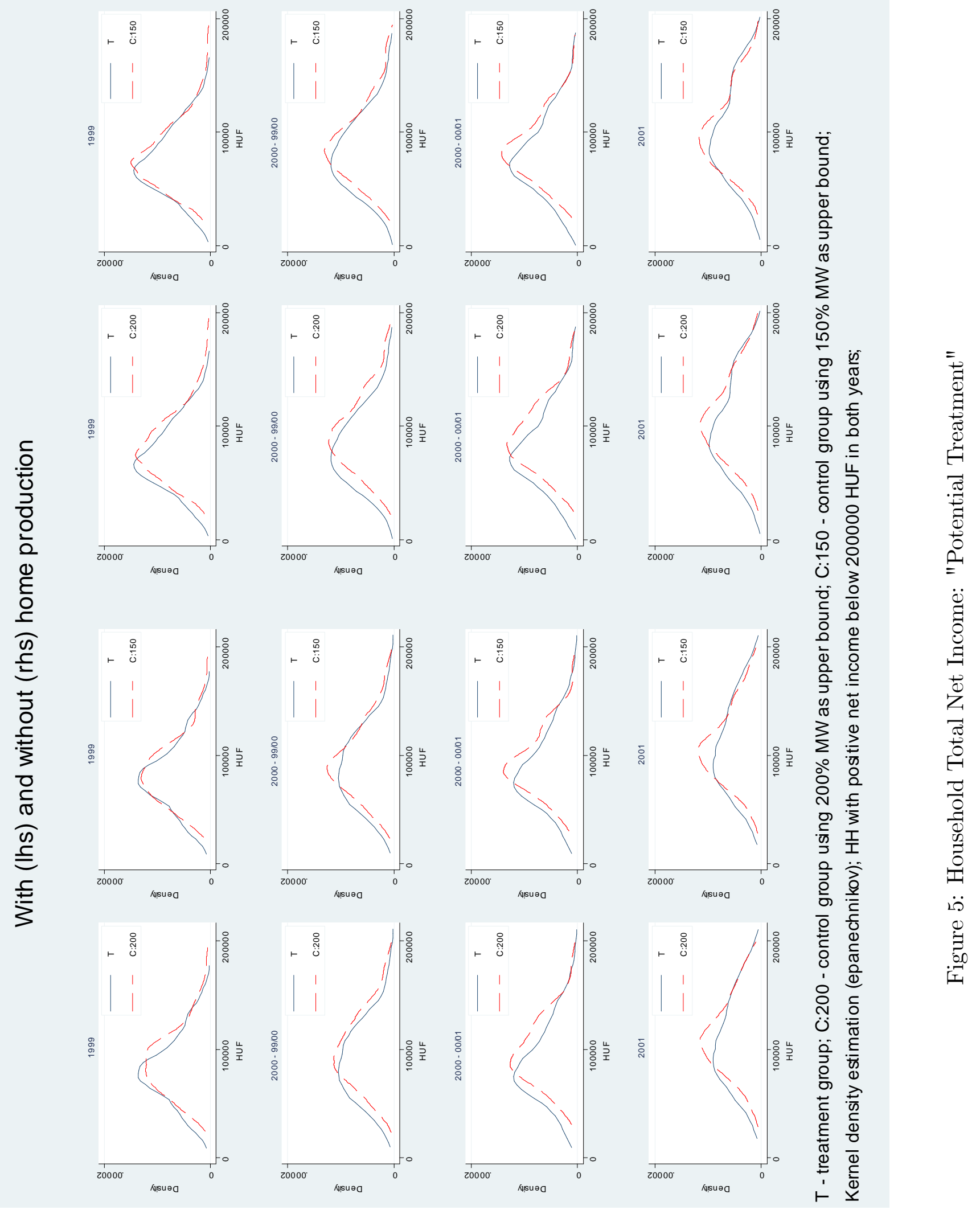


Figure 6: Relationship between market food consumption and income - "Potential Treatment" - Control Group 150

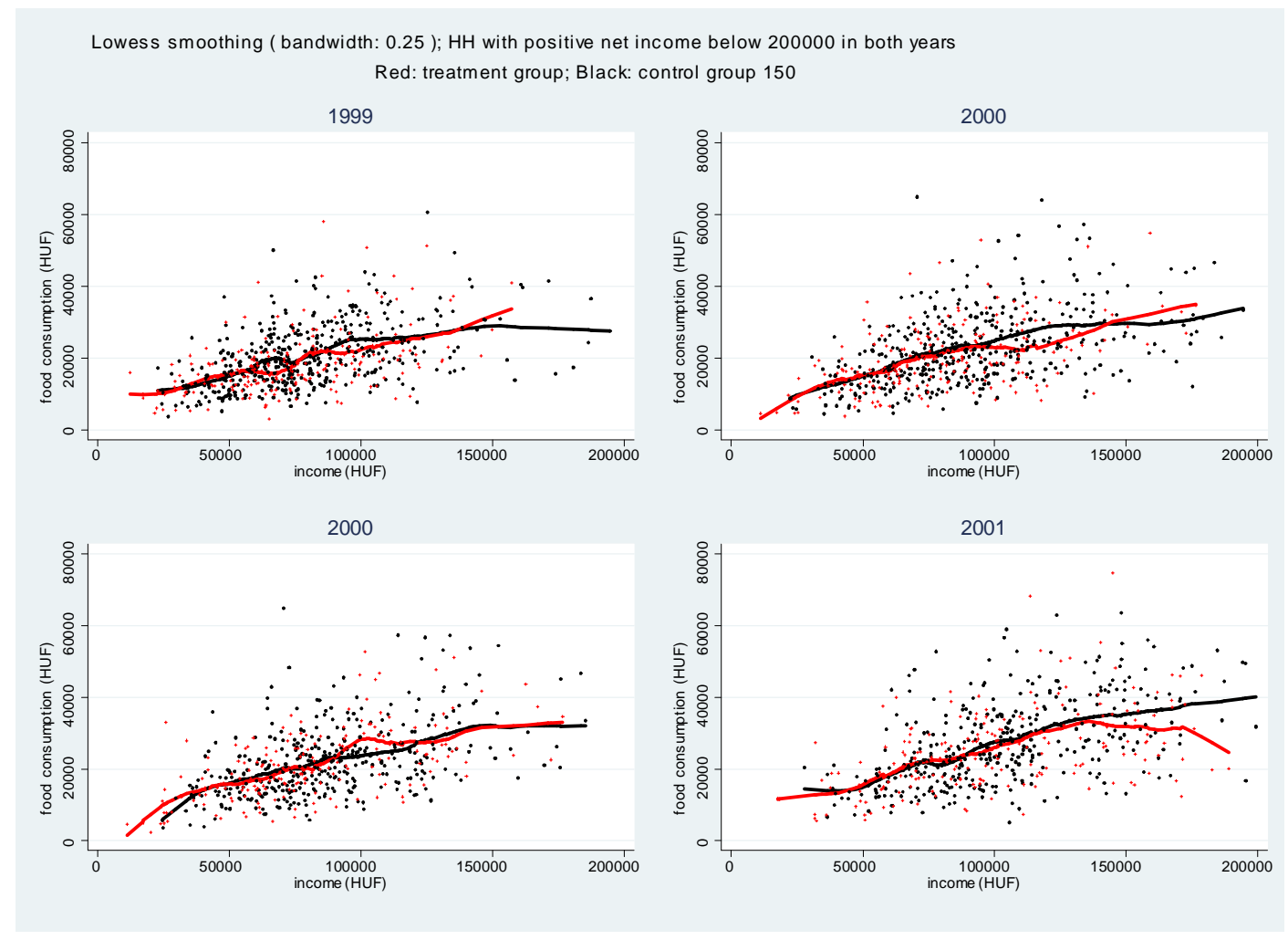


Figure 7: Relationship between market food consumption and income - "Potential Treatment" - Control Group 200

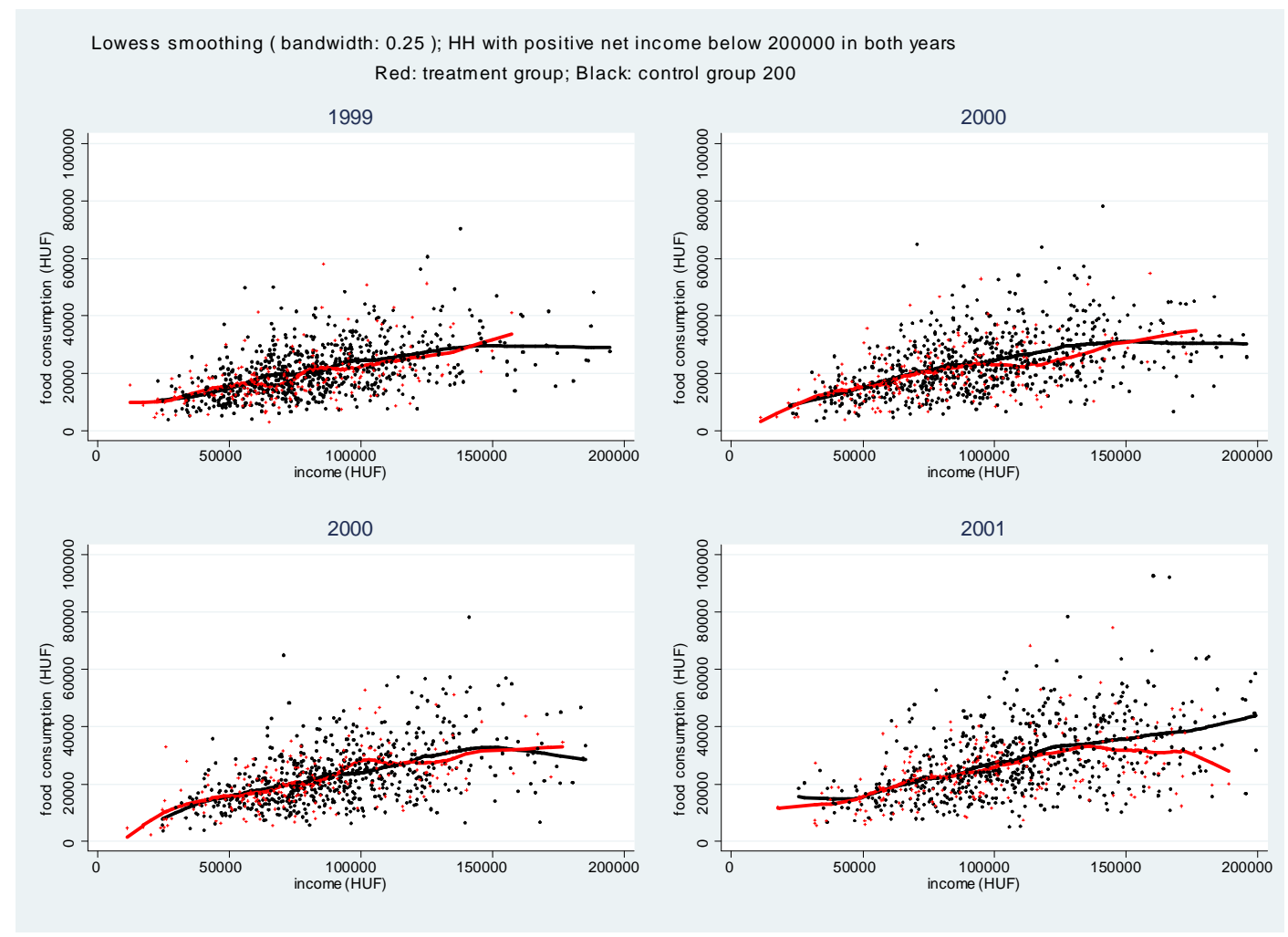




\section{Figure 8: Household Total Net Income: "Actual Treatment"}

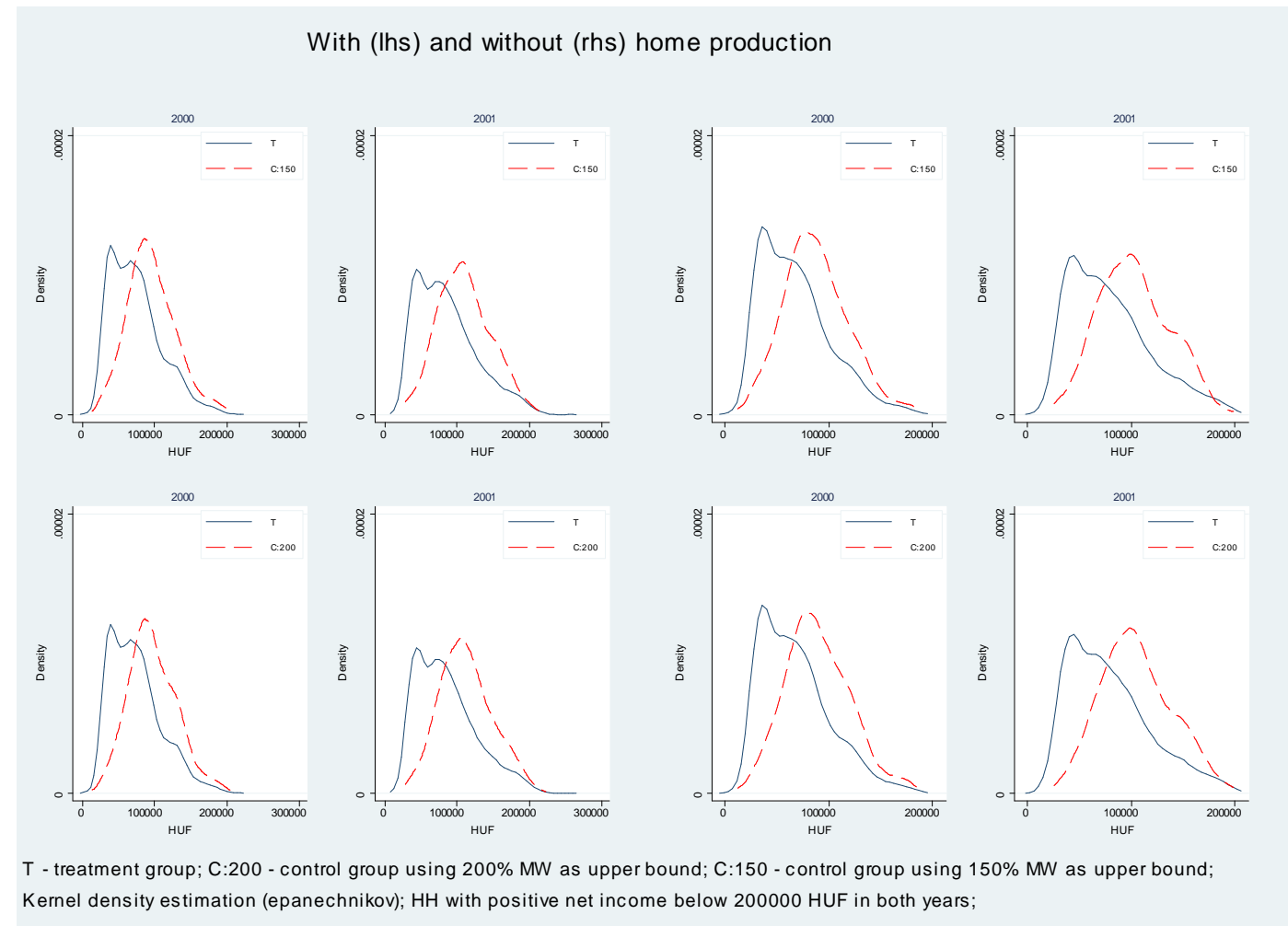


Figure 9: Relationship between market food consumption and income - "Actual Treatment"
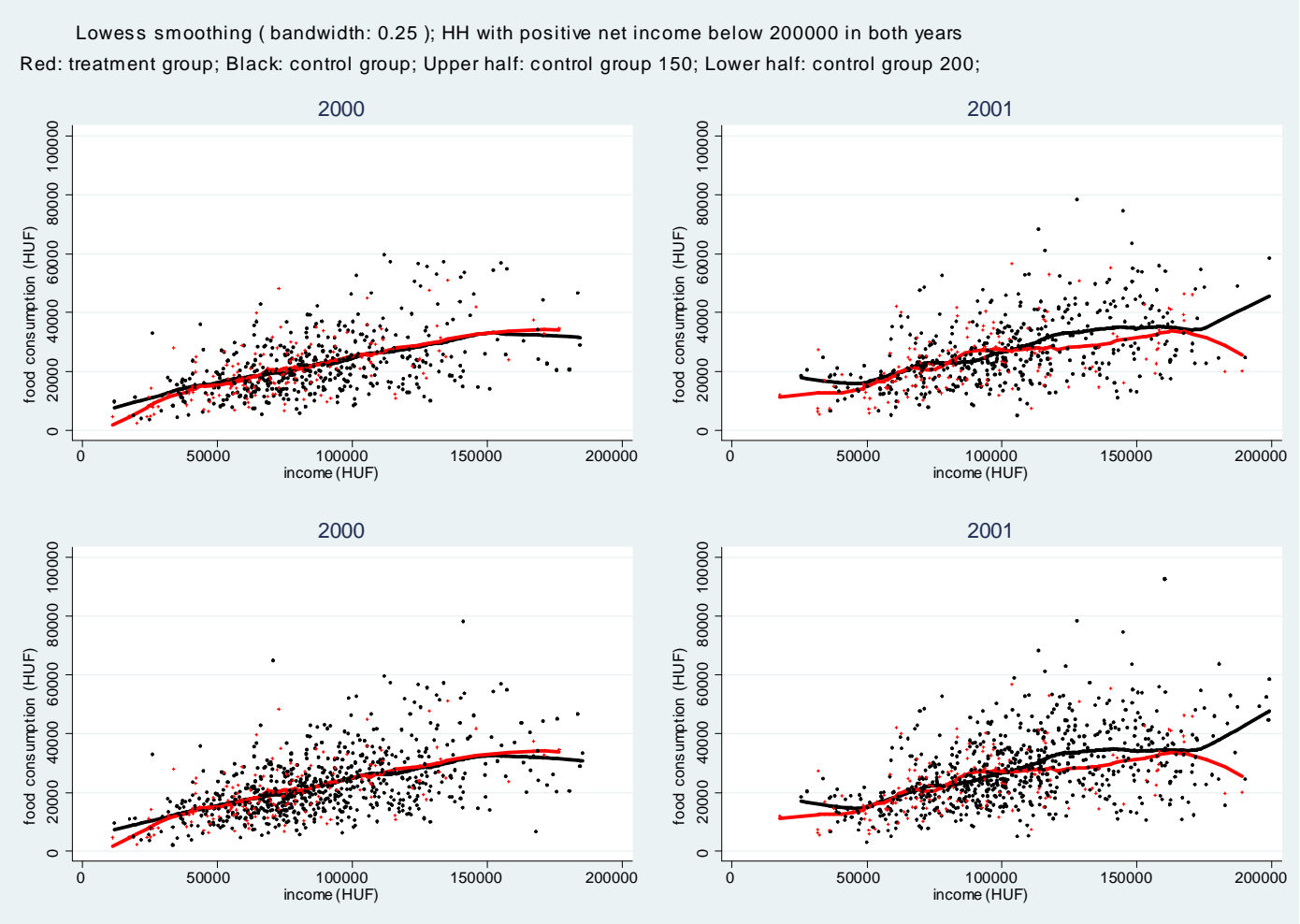


\section{DAVIDSON INSTITUTE WORKING PAPER SERIES - Most Recent Papers}

The entire Working Paper Series may be downloaded free of charge at: www.wdi.umich.edu

CURRENT AS OF 03/30/07

\begin{tabular}{|c|c|c|}
\hline Publication & Authors & Date \\
\hline $\begin{array}{l}\text { No. 865: Minimum Wage and Tax Evasion: Theory } \\
\text { and Evidence }\end{array}$ & Mirco Tonin & Jan 2007 \\
\hline $\begin{array}{l}\text { No. 864: Dynamics of the Financial Wealth of the Institutional Sectors in } \\
\text { Bulgaria: Empirical Studies of the Post-Communist Period }\end{array}$ & $\begin{array}{l}\text { Nikolay Nenovsky and Gergana } \\
\text { Mihaylova }\end{array}$ & $\begin{array}{l}\text { March } \\
2007\end{array}$ \\
\hline $\begin{array}{l}\text { No. 863: Impact of Derivatives Trading on Emerging Capital Markets: A } \\
\text { Note on Expiration Day Effects in India }\end{array}$ & $\begin{array}{l}\text { Sumon Kumar Bhaumik and } \\
\text { Suchismita Bose }\end{array}$ & $\begin{array}{l}\text { March } \\
2007\end{array}$ \\
\hline $\begin{array}{l}\text { No. 862: Short- \& Medium- Term Determinants of Current Account } \\
\text { Balances in Middle East \& North Africa Countries }\end{array}$ & Aleksander Aristovnik & $\begin{array}{l}\text { March } \\
2007\end{array}$ \\
\hline $\begin{array}{l}\text { No. 861: Time-Varying Comovements in Developed and Emerging } \\
\text { European Stock Markets: Evidence from Intraday Data }\end{array}$ & Balázs Égert and Evžen Kočenda & $\begin{array}{l}\text { March } \\
2007\end{array}$ \\
\hline $\begin{array}{l}\text { No: 860: Giving Children a Better Start: Preschool Attendance \& } \\
\text { School-Age Profiles }\end{array}$ & $\begin{array}{l}\text { Sam Berlinski, Sebastian Galiani } \\
\text { and Marco Manacorda }\end{array}$ & Jan 2007 \\
\hline $\begin{array}{l}\text { No. 859: Real Exchange Rates in Small open OECD \& Transition } \\
\text { Economies: Comparing Apples with Oranges? }\end{array}$ & $\begin{array}{l}\text { Balázs Égert, Kirsten } \\
\text { Lommatzsch and Amina } \\
\text { Lahreche-Revil }\end{array}$ & Jan 2007 \\
\hline $\begin{array}{l}\text { No. 858: Is Education the Panacea for Economic Deprivation of } \\
\text { Muslims? Evidence from Wage Earners in India, 1987-2004 }\end{array}$ & $\begin{array}{l}\text { Sumon Kumar Bhaumik and } \\
\text { Manisha Chakrabarty }\end{array}$ & Jan 2007 \\
\hline $\begin{array}{l}\text { No. 857: Human Capital, Economic Growth, and Regional Inequality in } \\
\text { China }\end{array}$ & $\begin{array}{l}\text { Belton Fleisher, Haizheng Li and } \\
\text { Min Qiang Zhao }\end{array}$ & Jan 2007 \\
\hline $\begin{array}{l}\text { No. 856: Does Better Environmental Performance Affect Revenues, } \\
\text { Costs, or Both? Evidence From a Transition Economy }\end{array}$ & $\begin{array}{l}\text { Dietrich Earnhart and Lubomir } \\
\text { Lizal }\end{array}$ & Feb 2007 \\
\hline No. 855: Media Coverage \& Charitable Giving After the 2004 Tsunami & Philip Brown and Jessica Minty & Dec 2006 \\
\hline $\begin{array}{l}\text { No. 854: Default Rates in the Loan Market for SMEs: Evidence from } \\
\text { Slovakia }\end{array}$ & $\begin{array}{l}\text { Jarko Fidrmuc, Christa Hainz and } \\
\text { Anton Maleisch }\end{array}$ & Nov 2006 \\
\hline $\begin{array}{l}\text { No. 853: Monetary Policy before Euro Adoption: Challenges for EU } \\
\text { New Members }\end{array}$ & $\begin{array}{l}\text { Jan Filáček, Roman Horváth and } \\
\text { Michal Skorepa }\end{array}$ & Nov 2006 \\
\hline $\begin{array}{l}\text { No. 852: Private-Sector Credit in Central \& Eastern Europe: New } \\
\text { (Over) Shooting Stars? }\end{array}$ & $\begin{array}{l}\text { Balázs Égert, Peter Backé and } \\
\text { Tina Zumer }\end{array}$ & Nov 2006 \\
\hline $\begin{array}{l}\text { No. 851: Interest Rate Pass-Through in Central \& Eastern Europe: } \\
\text { Reborn from Ashes Merely to Pass Away? }\end{array}$ & $\begin{array}{l}\text { Balázs Égert,Jesus Crespo- } \\
\text { Cuaresma and Thomas Reininger }\end{array}$ & Nov 2006 \\
\hline $\begin{array}{l}\text { No. 850: Monetary Transmission Mechanism in Central \& Eastern } \\
\text { Europe: Gliding on a Wind of Change }\end{array}$ & $\begin{array}{l}\text { Fabrizio Coricelli, Balázs Égert } \\
\text { and Ronald MacDonald }\end{array}$ & Nov 2006 \\
\hline No. 849: Crime Distribution \& Victim behavior During a Crime Wave & $\begin{array}{l}\text { Rafael Di Tella, Sebastian Galiani } \\
\text { and Ernesto Schargrodsky }\end{array}$ & Nov 2006 \\
\hline $\begin{array}{l}\text { No. 848: Real-Time Time-Varying Equilibrium Interest Rates: Evidence } \\
\text { on the Czech Republic }\end{array}$ & Roman Horváth & Oct 2006 \\
\hline $\begin{array}{l}\text { No. 847: Financial Accelerator Effects in the Balance Sheets of Czech } \\
\text { Firms }\end{array}$ & Roman Horváth & Nov 2006 \\
\hline $\begin{array}{l}\text { No. 846: Central Bank Interventions, Communication \& Interest Rate } \\
\text { Policy in Emerging European Economies }\end{array}$ & Balázs Égert & Nov 2006 \\
\hline $\begin{array}{l}\text { No. 845: On the Role of Absorptive Capacity: FDI Matters to } \\
\text { Growth }\end{array}$ & Yuko Kinishita and Chia-Hui Lu & Nov 2006 \\
\hline No. 844: Current Account Sustainability in Selected Transition Countries & Aleksander Aristovnik & Nov 2006 \\
\hline $\begin{array}{l}\text { No. 843: Policy, Economic Federalism \& Product Market Entry: The } \\
\text { Indian Experience }\end{array}$ & $\begin{array}{l}\text { Sumon Bhaumik, Shubhashis } \\
\text { Gangopadhyay and Shagun } \\
\text { Krishnan }\end{array}$ & Nov 2006 \\
\hline No. 842: Price Mobility of Locations & Konstantin Gluschenko & Oct 2006 \\
\hline
\end{tabular}

